\title{
Ocean acidification promotes broad transcriptomic responses in marine metazoans: a literature survey
}

\author{
Marie E. Strader ${ }^{1,2}$, Juliet M. Wong ${ }^{1,3}$ and Gretchen E. Hofmann ${ }^{1 *}$
}

\begin{abstract}
For nearly a decade, the metazoan-focused research community has explored the impacts of ocean acidification $(\mathrm{OA})$ on marine animals, noting that changes in ocean chemistry can impact calcification, metabolism, acid-base regulation, stress response and behavior in organisms that hold high ecological and economic value. Because OA interacts with several key physiological processes in marine organisms, transcriptomics has become a widely-used method to characterize whole organism responses on a molecular level as well as inform mechanisms that explain changes in phenotypes observed in response to OA. In the past decade, there has been a notable rise in studies that examine transcriptomic responses to $\mathrm{OA}$ in marine metazoans, and here we attempt to summarize key findings across these studies. We find that organisms vary dramatically in their transcriptomic responses to $\mathrm{pH}$ although common patterns are often observed, including shifts in acid-base ion regulation, metabolic processes, calcification and stress response mechanisms. We also see a rise in transcriptomic studies examining organismal response to $\mathrm{OA}$ in a multi-stressor context, often reporting synergistic effects of $\mathrm{OA}$ and temperature. In addition, there is an increase in studies that use transcriptomics to examine the evolutionary potential of organisms to adapt to OA conditions in the future through population and transgenerational experiments. Overall, the literature reveals complex organismal responses to $\mathrm{OA}$, in which some organisms will face more dramatic consequences than others. This will have wide-reaching impacts on ocean communities and ecosystems as a whole.
\end{abstract}

Keywords: Ocean acidification, Transcriptomics, Marine metazoans, Metabolism, Calcification, Gene expression

\section{Background}

In 1999, coral biologists first raised concerns about how changes in the saturation state of seawater might impact calcification in this foundation taxon [1]. Other marine biologists followed suit with studies reviewing impacts on plankton [2] with the first studies on other marine metazoans appearing in 2004 [3]. Shortly thereafter, chemical oceanographers and modelers described the process of ocean acidification (OA) and provided predictions regarding the rate of change in ocean chemistry; this has framed the timing on the impacts of OA on marine biota [4-6]. Over the last decade, the OA research community has made significant progress identifying vulnerabilities in our food systems and ecosystems using a variety of techniques

\footnotetext{
*Correspondence: hofmann@ucsb.edu

'Department of Ecology, Evolution and Marine Biology, University of California Santa Barbara, Santa Barbara, CA 93106, USA

Full list of author information is available at the end of the article
}

ranging from marine materials methods to genomics. While some species are robust to changes associated with OA (i.e., under-saturated conditions), others are highly sensitive, which will have far reaching implications on ocean systems. In natural systems that mimic OA, there are significant reductions in biodiversity and functional richness along $\mathrm{CO}_{2}$ gradients [7]. Losses of key species will drive changes in food-web dynamics, habitat restructuring and reductions in marine resources that support human societies [8].

Accumulated past research has highlighted vulnerabilities in calcification-dependent metazoans, which are sensitive to changes in carbonate chemistry, noting that there is a great deal of variability that depends on taxa as well as evolutionary and environmental history [9, 10]. OA negatively impacts traits such as calcification, growth, reproduction and survival in some calcifying taxa, while traits remain neutral in others [9]. Other 
reviews have illuminated the effects of $\mathrm{OA}$ on ecosystem processes [11, 12], physiological responses of organisms $[9,13]$, important parts of food systems, including shellfish aquaculture [14-16] and energy transfer across trophic levels [17-19]. Here, we provide an overview of how the transcriptome, a sensitive physiological trait [20], shifts in response to OA in marine metazoans, and what these transcriptomic responses represent in the context of other traits. We highlight the general commonality in findings across studies, exceptions to these trends, and important factors worthy of additional consideration, such as life-history and co-occurring environmental stressors.

There has been a consistent increase in recently published works that incorporate transcriptomics in the study of organismal responses to OA: $76.1 \%$ of publications with 'ocean acidification' and 'gene expression' in the title or abstract have been published in the past 5 years (Fig. 1). Since changes in seawater chemistry impact physiological traits such as ion transport, metabolism and calcification, transcriptomics is an effective method for examining a molecular-level response that, when paired with phenotypic data, can elucidate mechanistic underpinnings for whole organism responses to $\mathrm{OA}$. The increase in these studies emphasizes that transcriptome profiling is a robust and informative means by which to characterize how organisms are affected by environmental change.

\section{Overview of the studies}

Analysis of differential gene expression has been used to generate important observations about the response of marine metazoans to OA (Table 1). However, these studies can differ greatly in their approach, varying in the examined life-history stage, $\mathrm{pH}$ levels, exposure duration, and interactions in a multi-stressors framework
(Fig. 2). For the most part, experiments have been conducted in the laboratory, although some studies have examined population-specific differences in gene expression across natural $\mathrm{pH}$ gradients in the field, illuminating how long term adaptation or acclimatization has impacted the transcriptome [23, 44, 78, 79, 87]. In addition, some studies have investigated organismal responses to acidifying conditions across two or more generations, providing further insight into the extent of phenotypic plasticity in an OA context $[55,80,88,89]$. In our review of the literature, we found core transcriptomic responses to OA, but diversity in the ability of organisms to tolerate different $\mathrm{pH}$ environments. Below we summarize the collective results of these studies, noting five areas where gene expression analysis has contributed to our understanding of the physiology of marine animals and their response to OA. These key observations are that organisms: (1) differentially regulate metabolic pathways, (2) modulate genes involved in calcification and skeletogenesis, (3) activate the cellular stress response, (4) regulate acid-base ion transport mechanisms, and (5) alter behaviors. In addition, we note that there are often discrepancies between organismal responses to OA across life-history stages, where planktonic larvae and juveniles may be more sensitive to OA. Further, we examine the impacts of OA in the context of co-occurring multi-stressors and the evolutionary potential of organisms to adapt to OA.

\section{Observation 1: Organisms alter metabolic processes under exposure to low $\mathrm{pH}$}

As $\mathrm{CO}_{2}$ is absorbed into surface oceans, excess $\mathrm{CO}_{2}$ diffuses into extra- and intra-cellular compartments of marine organisms. Metabolic depression is a mechanism by which organisms conserve energy while cells actively work to decrease the influx in $\mathrm{H}^{+}$ions through ion

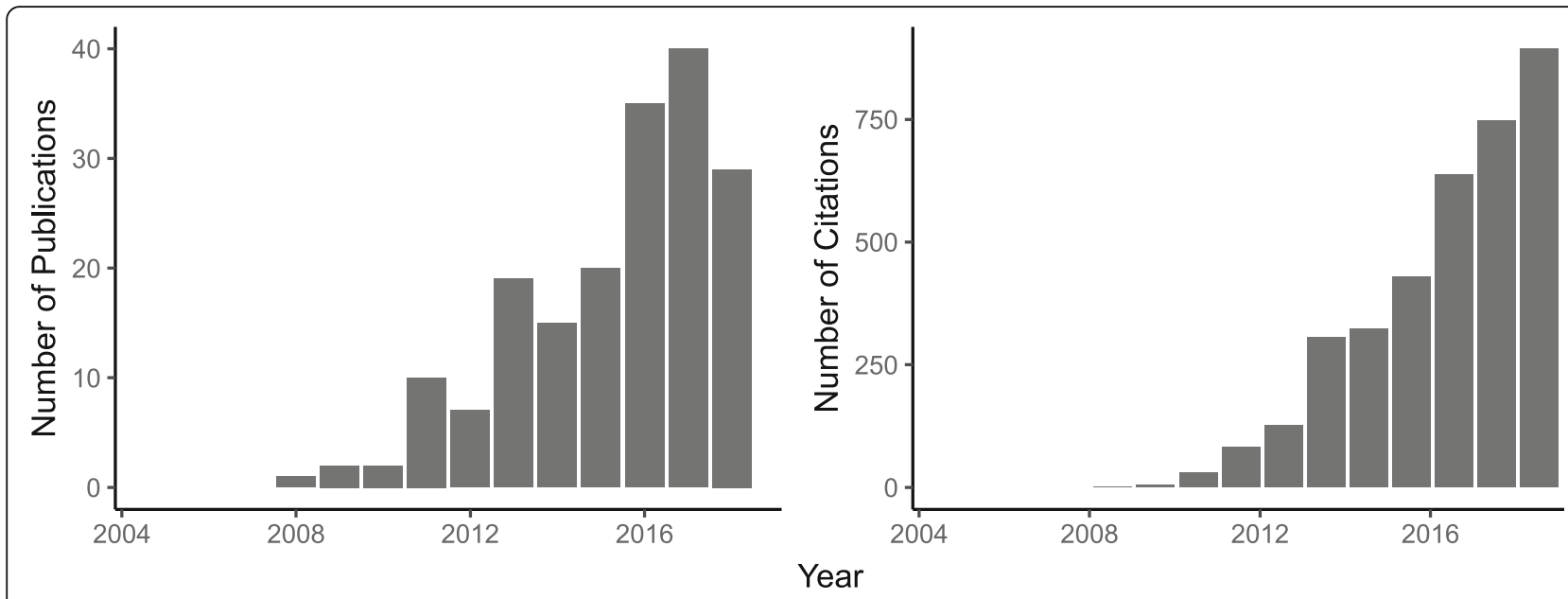

Fig. 1 Web of Science search summarizing the number of papers and citations for papers with terms "ocean acidification" and "gene expression" 
Table 1 Gene expression studies examining the response of marine metazoans to $O A$

\begin{tabular}{|c|c|c|c|c|}
\hline Phylum & Taxon & Species & Life-Stage & References \\
\hline \multirow[t]{12}{*}{ Cnidaria } & \multirow[t]{12}{*}{ Coral } & \multirow[t]{2}{*}{ Acropora millepora } & Larvae/Juvenile & {$[21,22]$} \\
\hline & & & Adult & {$[23-26]$} \\
\hline & & Acropora aspera & Adult & {$[27]$} \\
\hline & & Acropora gemmifera & Larvae & {$[28]$} \\
\hline & & Balanophyllia europaea & Adult & {$[29]$} \\
\hline & & Balanophyllia elegans & Adult & {$[30]$} \\
\hline & & Desmophyllum dianthus & Adult & {$[31]$} \\
\hline & & \multirow[t]{2}{*}{ Pocillopora damicornis } & Larvae & {$[32]$} \\
\hline & & & Adult & {$[33]$} \\
\hline & & Siderastrea siderea & Adult & {$[34]$} \\
\hline & & \multirow[t]{2}{*}{ Stylophora pistillata } & Adult & {$[29,35]$} \\
\hline & & & Cell culture & {$[36]$} \\
\hline \multirow[t]{2}{*}{ Annelida } & \multirow[t]{2}{*}{ Polychaete } & Platynereis dumerilii & Adult & {$[37,38]$} \\
\hline & & Platynereis cfr massiliensis & Adult & {$[37]$} \\
\hline \multirow[t]{19}{*}{ Mollusca } & Abalone & Haliotis rufescens & Larvae & {$[39]$} \\
\hline & \multirow[t]{2}{*}{ Clam } & Ruditapes philippinarum & Adult & {$[40]$} \\
\hline & & Sinonovacula constricta & Adult & {$[41]$} \\
\hline & \multirow[t]{3}{*}{ Mussel } & Mytilus californianus & Larvae & {$[42]$} \\
\hline & & Mytilus coruscus & Adult & {$[43]$} \\
\hline & & Mytilus edulis & Adult & {$[44,45]$} \\
\hline & \multirow[t]{5}{*}{ Oyster } & \multirow[t]{2}{*}{ Crassostrea gigas } & Larvae & {$[46]$} \\
\hline & & & Adult & {$[47,48]$} \\
\hline & & Crassostrea virginica & Adult & {$[49]$} \\
\hline & & Pinctada fucata & Adult & {$[50-54]$} \\
\hline & & Saccostrea glomerata & Adult & {$[55-57]$} \\
\hline & \multirow[t]{6}{*}{ Pteropod } & Clio pyramidata & Adults & {$[58]$} \\
\hline & & Clione limacina & Adults & {$[59]$} \\
\hline & & Heliconoides inflatus & Adults & {$[60]$} \\
\hline & & Limacina helicina & Adults & {$[61]$} \\
\hline & & Limacina helicina antarctica & Juveniles & {$[62]$} \\
\hline & & Limacina retroversa & Adults & {$[63]$} \\
\hline & Scallop & Pecten maximus & Adults & {$[44]$} \\
\hline & Snail & Crepidula fornicata & Larvae & {$[64]$} \\
\hline \multirow[t]{6}{*}{ Arthropoda } & \multirow[t]{3}{*}{ Copepod } & Acartia tonsa & Adults & {$[65]$} \\
\hline & & Calanus glacialis & Larvae & {$[66]$} \\
\hline & & Pseudocalanus acuspes & Adults & {$[67]$} \\
\hline & \multirow[t]{3}{*}{ Crab } & Carcinus maenas & Adults & {$[68,69]$} \\
\hline & & Hyas araneus & Larvae & {$[70]$} \\
\hline & & & Adults & {$[71]$} \\
\hline \multirow[t]{5}{*}{ Echinodermata } & Brittle star & Amphiura filiformis & Adults & {$[72]$} \\
\hline & \multirow[t]{4}{*}{ Sea urchin } & Hemicentrotus pulcherrimus & Embryos/Larvae & {$[73]$} \\
\hline & & Lytechinus pictus & Larvae & {$[74]$} \\
\hline & & Mesocentrotus franciscanus & Larvae & {$[75]$} \\
\hline & & Paracentrotus lividus & Embryos/Larvae & {$[76]$} \\
\hline
\end{tabular}


Table 1 Gene expression studies examining the response of marine metazoans to OA (Continued)

\begin{tabular}{|c|c|c|c|c|}
\hline Phylum & Taxon & Species & Life-Stage & References \\
\hline & & Strongylocentrotus droebachiensis & Larvae & [77] \\
\hline & & Strongylocentrotus purpuratus & Embryos/Larvae & [78-86] \\
\hline & & & Adults & {$[87]$} \\
\hline \multirow[t]{9}{*}{ Chordata } & Fish & Acanthochromis polyacanthus & Juveniles & {$[88,89]$} \\
\hline & & Dicentrarchus labrax & Larvae & [90] \\
\hline & & Gadus morhua & Adults & {$[91,92]$} \\
\hline & & Oryzias latipes & Embryos/Hatchlings/Adults & [93] \\
\hline & & Pagothenia borchgrevinki & Adults & [94] \\
\hline & & Sciaenops ocellatus & Adults & [95] \\
\hline & & Sebastes caurinus & Juveniles & [96] \\
\hline & & Sebastes mystinus & Juveniles & [96] \\
\hline & & Trematomus bernacchii & Adults & [97] \\
\hline
\end{tabular}

exchange processes [13]. Metabolic depression is typically an acute response since chronic reductions in metabolic processes can become lethal. While studies have investigated metabolic rates and ATP production in response to $\mathrm{pH}$ [98], gene expression has become another tool to assess the potential for metabolic depression, especially to elucidate mechanisms of this response (Table 2). Gene expression studies reporting metabolic depression in marine metazoans include adult blue mussels [45], adult pearl oysters [50,51], purple sea urchin larvae [81, 82], temperate brittle stars [72], clams [41], Arctic copepods [66], developing Medaka fish [93], marine polychaetes [37] and reef-building corals [21, 24-26]. Despite being commonly observed across gene expression studies in response to low $\mathrm{pH}$, the means by which metabolic depression is characterized through gene expression data varies by study and taxon.
One line of evidence that predicts metabolic depression is changes in transcripts that modulate the production of ATP. This has been observed in both calcifying and non-calcifying marine taxa. In adult mantel tissue of blue mussels, Mytilus edulis, a downregulation of 2 subunits of ATP-synthase occurs under 1120 and 2400 $\mu$ atm but not at $4000 \mu \mathrm{atm}$ [45]. This is in line with results found in purple sea urchin, Strongylocentrotus purpuratus, larvae; genes associated with the production of ATP and the tricarboxylic acid cycle (TCA), are downregulated in response to moderate $p \mathrm{CO}_{2}(540 \mathrm{ppm})$ [81] Follow-up studies suggest that rather than a decreased production of ATP in response to OA, S. purpuatus larvae reallocate the total ATP produced; more ATP goes toward protein synthesis and ion transport when exposed to high $p \mathrm{CO}_{2}$, leaving less energy to maintain other cellular functions [83]. However, larvae from

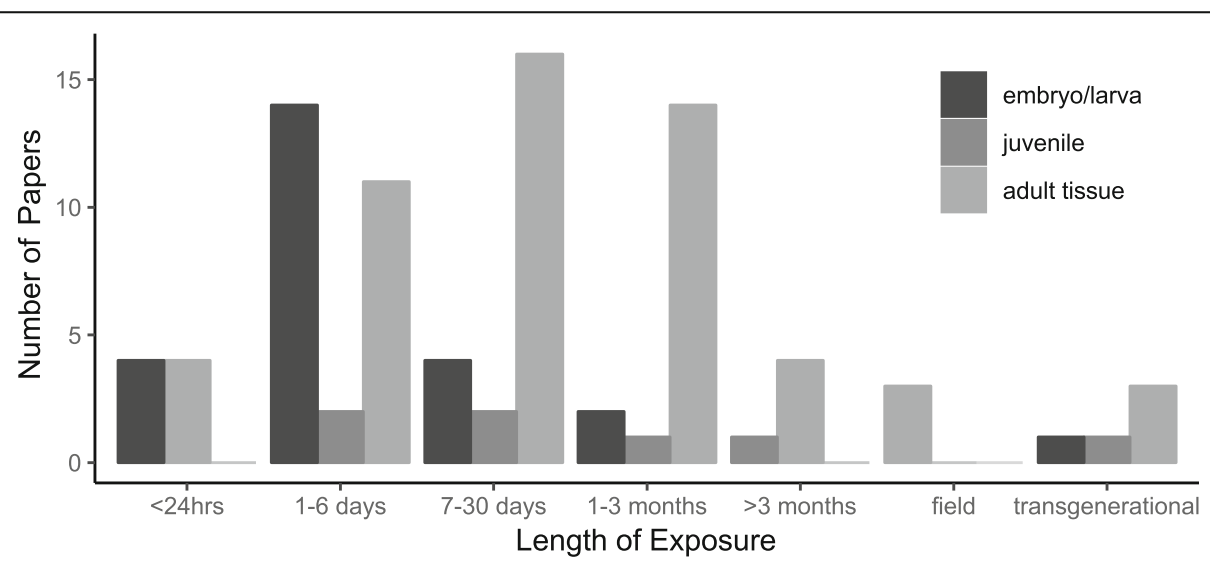

Fig. 2 Exposure times in studies examining gene expression responses to ocean acidification across life-history stages. Field studies include those where samples were collected directly from field sites with different $\mathrm{pH}$ regimes. Transgenerational studies include those that examine progeny responses to $\mathrm{pH}$ stress after parental or grandparental conditioning in different $\mathrm{pH}$ environments. Gray scales represent the stage of the life-cycle sampled for gene expression analysis 
Table 2 Impacts of high $p \mathrm{CO}_{2}$ on gene expression and oxygen consumption in marine invertebrate taxa. 'Metabolic genes' is a broad term that encompasses any metabolic processes as defined independently in each study. Arrows denote the direction of the response. In instances with both arrows, this reflects either overall differential expression (genes being both up and down regulated), or conflicting results across studies or life-history stages. Dashes indicate a non-significant response. It should be noted that oxygen consumption and gene expression measurements for a particular species may be confined to separate independent studies. Exposure duration and range of $\mathrm{pCO}_{2}$ tested are inclusive to all studies on noted species. In studies where $p \mathrm{CO}_{2}$ was not calculated (or only calculated in some studies), $\mathrm{pH}$ values are given. $\mathrm{Hpf}=$ hour post fertilization, $\mathrm{dpf}=$ days post fertilization, $\mathrm{d}=$ days, $h=$ hour, $w k=$ weeks, $m o=$ months, field = organisms sampled from variable habitats in the field, generation = exposure carried out across multiple generations

\begin{tabular}{|c|c|c|c|c|c|c|}
\hline \multicolumn{7}{|l|}{ Metabolism } \\
\hline Phylum & Species & $\begin{array}{l}\text { Metabolic genes in } \\
\text { response to high } p \mathrm{CO}_{2}\end{array}$ & $\begin{array}{l}\text { Oxygen consumption measured / } \\
\text { response in high } p \mathrm{CO}_{2}\end{array}$ & $\begin{array}{l}\text { Exposure } \\
\text { duration }\end{array}$ & $\begin{array}{l}\text { Range of } p \mathrm{CO}_{2} \\
\text { tested }(\mu \mathrm{atm})\end{array}$ & References \\
\hline \multirow[t]{6}{*}{ Cnidaria } & Acropora aspera & $\uparrow$ or $\downarrow$ & $\mathrm{N}$ & $14 \mathrm{~d}$ & $142-827$ & {$[27]$} \\
\hline & Acropora millepora & $\downarrow$ or - & $\mathrm{N}$ & $1 \mathrm{~h}$ - Field & $325-1638$ & {$[21-26]$} \\
\hline & $\begin{array}{l}\text { Balanophyllia } \\
\text { elegans }\end{array}$ & $\uparrow$ or $\downarrow$ & $Y /$ - or $\downarrow$ & $29 d$ & $785-2367$ & {$[30]$} \\
\hline & $\begin{array}{l}\text { Desmophyllum } \\
\text { dianthus }\end{array}$ & $\uparrow$ & $Y / \uparrow$ & $8 \mathrm{mo}$ & 460-997 & [31] \\
\hline & $\begin{array}{l}\text { Pocillopora } \\
\text { damicornis }\end{array}$ & $\uparrow$ or - & $Y / \downarrow$ & $\begin{array}{c}24 h-1.5 \\
\text { mo }\end{array}$ & $417-3879$ & $\begin{array}{l}{[32,33,99,} \\
100]\end{array}$ \\
\hline & Siderastrea siderea & $\uparrow$ & N & $95 d$ & $280-2800$ & [34] \\
\hline \multirow[t]{12}{*}{ Mollusca } & Clio pyramidata & $\downarrow$ or - & $Y /-$ & $10 \mathrm{~h}$ & $280-800$ & {$[58]$} \\
\hline & Crassostrea gigas & $\downarrow$ or - & Y/ - & 18hpf-3mo & 449-1515 & {$[46,48]$} \\
\hline & Crassostrea virginica & $\uparrow$ or $\downarrow$ & $\mathrm{N}$ & Field & $\mathrm{pH}: 7.2-8.0$ & {$[49]$} \\
\hline & Crepidula fornicata & $\downarrow$ & $\mathrm{N}$ & $12 \mathrm{~d}$ & $504-1480$ & {$[64]$} \\
\hline & Heliconoides inflata & $\downarrow$ & $Y /-$ & $3 d$ & $382-720$ & {$[60]$} \\
\hline & $\begin{array}{l}\text { Limacina helicina } \\
\text { antarctica }\end{array}$ & $\downarrow$ & $\mathrm{Y} / \uparrow$ & $1-21 d$ & 215-961 & {$[62,101]$} \\
\hline & Limacina retroversa & $\uparrow$ or $\downarrow$ & $Y / \uparrow$ & $1-21 d$ & $464-1177$ & {$[63]$} \\
\hline & Mytilus californianus & - & $\mathrm{N}$ & $63 \mathrm{hpf}$ & $345-1411$ & {$[42]$} \\
\hline & Mytilus edulis & $\downarrow$ & $Y / \uparrow$ & $2 \mathrm{~d}-2 \mathrm{mo}$ & $385-4000$ & {$[45,102,103]$} \\
\hline & Pinctada fucata & $\downarrow$ & $Y /-$ & $0.5 \mathrm{~h}-2 \mathrm{mo}$ & $\mathrm{pH}: 7.4-8.1$ & $\begin{array}{l}{[50,51,53,} \\
104]\end{array}$ \\
\hline & $\begin{array}{l}\text { Saccostrea } \\
\text { glomerata }\end{array}$ & $\uparrow$ or $\downarrow$ & $Y / \uparrow$ & $\begin{array}{l}1 \text { wk. }-5 \\
\text { wks }\end{array}$ & $380-1329$ & {$[55-57,105]$} \\
\hline & $\begin{array}{l}\text { Sinonovacula } \\
\text { constricta }\end{array}$ & $\uparrow$ & $Y / \downarrow$ & 1 wk & $549-3064$ & [41] \\
\hline Annelida & Platynereis spp. & $\uparrow$ or - & $Y / \uparrow$ & $5 d-7 d$ & $478-6534$ & {$[37,106]$} \\
\hline \multirow[t]{3}{*}{ Arthropoda } & Calanus glacialis & $\downarrow$ & $Y /-$ & $35-38 d$ & $320-1700$ & {$[66,107]$} \\
\hline & Hyas araneus & $\uparrow$ or $\downarrow$ & $Y /-$ or $\downarrow$ & $9 d-10 w k s$ & $420-3300$ & {$[70,71]$} \\
\hline & $\begin{array}{l}\text { Pseudocalanus } \\
\text { acuspes }\end{array}$ & $\uparrow$ or $\downarrow$ & $Y / \uparrow$ & generations & $400-1550$ & {$[67,108]$} \\
\hline \multirow[t]{5}{*}{ Echinodermata } & Amphiura filiformis & $\downarrow$ & $Y / \downarrow$ & 4 wks & $492-6399$ & {$[72]$} \\
\hline & Lytechinus pictus & $\downarrow$ & $\mathrm{N}$ & $142 \mathrm{hpf}$ & $280-970$ & [74] \\
\hline & Paracentrotus lividus & - & $\mathrm{N}$ & $3 d$ & $397-6590$ & {$[76]$} \\
\hline & $\begin{array}{l}\text { Strongylocentrotus } \\
\text { droebachiensis }\end{array}$ & $\downarrow$ & $\mathrm{N}$ & $\begin{array}{l}5.4 \mathrm{dpf}- \\
16 \mathrm{mo}\end{array}$ & $400-1200$ & {$[77,109]$} \\
\hline & $\begin{array}{l}\text { Strongylocentrotus } \\
\text { purpuratus }\end{array}$ & $\uparrow$ or $\downarrow$ & $\mathrm{Y} / \uparrow,-$ or $\downarrow$ & $\begin{array}{c}40 \mathrm{hpf}-21 \\
\mathrm{dpf}\end{array}$ & 380-9556 & $\begin{array}{l}{[74,81,82} \\
84,85,110]\end{array}$ \\
\hline
\end{tabular}


populations of $S$. purpuratus experiencing frequent low $\mathrm{pH}$ episodes in nature upregulate metabolic processes, including genes in the TCA, suggesting these populations have adapted by constitutively expressing genes that enable higher ATP production [78]. These studies emphasize that a core response of marine metazoans to decreases in $\mathrm{pH}$ involves a reallocation and/or changes in production of ATP, often as a trade-off in maintaining ion homeostasis, calcification and control of internal $\mathrm{pH}$ levels. Modulation of ATP-producing enzymes has also been reported in non-calcifying marine organisms in response to low $\mathrm{pH}$, including Arctic copepods [66] and within brains of coral reef fish [89].

Another commonly reported gene expression signature that predicts metabolic depression is changes in genes involved in mitochondrial and oxidative metabolism. This is particularly evident in some species of reefbuilding corals, whose metabolism is complicated by their obligate symbiosis with algae in the family Symbiodiniaceae. Adult Acropora millepora show signatures of metabolic depression after $p \mathrm{CO}_{2}$ stress, although results are varied. Exposure for 14 days to a $p \mathrm{CO}_{2}$ up to $1638 \mu \mathrm{atm}$ showed no regulation of metabolic candidate genes [26], yet adult exposure to longer periods of $p \mathrm{CO}_{2}$ stress, (i.e., 28 days at 1010-1350 $\mu$ atm [24], 35 days at $997 \mu \mathrm{atm}$ [25] and 37 days at $886 \mu \mathrm{atm}$ [26]) elicited a response indicative of metabolic depression, including genes involved in the TCA cycle, ATP and NADPH production, oxidative metabolism and the mitochondrion electron transport chain. Acute $p \mathrm{CO}_{2}$ exposure of early juveniles of $A$. millepora decreased expression of mitochondrion and oxidative metabolism genes, but only in the highest $p \mathrm{CO}_{2}$ treatments $(1000 \mathrm{ppm})$ [21], a result not found when juveniles were exposed to high $p \mathrm{CO}_{2}$ stress immediately following fertilization [22]. This suggests that despite metabolic depression early in exposure, early life-history stages of corals have a remarkable ability to acclimate to higher $p \mathrm{CO}_{2}$ levels over more prolonged periods of time, while adults only employ signs of metabolic depression under longer term, high $p \mathrm{CO}_{2}$ exposure. This observation does not seem to hold for all early life-history stages of corals. In Pocillopora damicornis larvae from French Polynesia, there was no observable change in expression of metabolism-related genes after an acute $24 \mathrm{~h}$ exposure to high $p \mathrm{CO}_{2}(\sim 1030 \mu \mathrm{atm})$ [33]. Overall, reef-building corals vary in how they regulate their metabolism in response to elevated $p \mathrm{CO}_{2}$ even during early life-history stages, providing evidence that early stages might be more robust to environmental variability than previously predicted.

Additional studies on reef-building corals suggest increases in metabolic processes under high $p \mathrm{CO}_{2}$ conditions. In another acroporid, Acropora aspera, Ogawa et al. [27] found an upregulation of three candidate metabolism genes (i.e., GAPDH, Glycogen phosphorylase and Glycogen synthase) when simultaneously exposed to the maximum temperature of the experiment (4 days) and a downregulation after temperature was returned to a consistent $+2{ }^{\circ} \mathrm{C}$ heat stress [27], an experimental design aimed to simulate a bleaching event with concurrent elevated $p \mathrm{CO}_{2}(\sim 800 \mu \mathrm{atm})$. Experiments exposing adult $P$. damicornis, which is likely a species complex, to $2180 \mu \mathrm{atm} p \mathrm{CO}_{2}$ for 3 weeks also found an upregulation of functional categories associated with metabolism, particularly oxidative phosphorylation, glycolysis and lipid and protein metabolic processes [32]. A highly stress-tolerant Caribbean coral Siderastrea siderea also exhibited elevated expression of metabolismrelated genes under high $p \mathrm{CO}_{2}(2553 \mu \mathrm{atm})$, including genes associated with oxidative metabolism related to the mitochondrion [34]. These increases in metabolic processes while experiencing high $p \mathrm{CO}_{2}$ levels suggest that maintaining calcification under extremely acidified conditions requires higher metabolic demands in these species; although it is key to note that the high $p \mathrm{CO}_{2}$ levels tested in [32, 34], $2180 \mu \mathrm{atm}$ and $2553 \mu \mathrm{atm}$, respectively, are not likely to be ecologically relevant. This difference in response compared with other reefbuilding corals suggests that some species may have evolved divergent physiological strategies for mitigating exposure to high $p \mathrm{CO}_{2}$. These strategies likely reflect different mechanisms of maintaining homeostasis during high $p \mathrm{CO}_{2}$ events. It must be noted, however, that the magnitude of overall transcriptomic response to elevated $p \mathrm{CO}_{2}$ in reef-building corals is relatively low $[21,22,26$, 34] compared to other stressors, suggesting robust mechanisms to tolerate forecasted OA scenarios. In addition, mechanisms to mitigate excess $\mathrm{H}^{+}$ions likely vary based on the length and the magnitude of high $p \mathrm{CO}_{2}$ exposure.

Organisms employ different mechanisms of metabolic responses based on length of exposure to stressors. Upregulation of genes involved in lipid metabolism is observed in many studies of long-term $p \mathrm{CO}_{2}$ stress response in a variety of taxa: reef-building corals $[21,23$, 25, 32], pteropods [62, 63], and Arctic copepods [66]. Concurrently, there are studies reporting increased lipid content in corals after exposure to increased $p \mathrm{CO}_{2}[111$, 112]. Presumably, under long-term exposure to high $p \mathrm{CO}_{2}$, corals increase their production of lipids to compensate for reductions in skeletal growth. There is also differential regulation of fatty acid metabolism in S. purpuratus from populations experiencing variable $\mathrm{pH}$ regimes [78]. Increasing lipid and carbohydrate metabolism has been suggested as a mechanism to sustain calcification and ion homeostasis when experiencing long exposures of low $\mathrm{pH}$, either episodically, as in upwelling scenarios, or chronically, as in volcanic $\mathrm{CO}_{2}$ 
vents. Long-term acclimation or adaptation to chronic $\mathrm{pH}$ stress likely involves modulation of lipid metabolism towards favoring lipid storage.

Although signatures of metabolic depression in response to $\mathrm{pH}$ are common, these patterns can often be complex and context dependent, often times only observed in response to extreme $\mathrm{pH}$. Temperate brittle stars, Amphiura filiformis, live in burrows that vary in $\mathrm{pH}$ depending on depth. Laboratory experiments show an increase in resting metabolic rate under low $\mathrm{pH}$ levels naturally experienced in their burrows ( $\mathrm{pH} 7.3$ ), while animals exposed to more extreme $\mathrm{pH}$ values (7.0) showed a decrease in metabolic rate and a reduced capacity to regenerate broken arms [72]. These physiological measures are supported by gene expression, which show reduced expression of key metabolic genes (Lactate dehydrogenase and Glucose 6-phosphate dehydrogenase) [72].

Studies of transcriptomic responses to high $p \mathrm{CO}_{2} /$ low $\mathrm{pH}$ exposure in shell-forming zooplankton show dramatic modulation of energetic processes. Both Arctic copepods and Antarctic pteropods show massive downregulation of much of the transcriptome after low $\mathrm{pH}$ exposure (1700 $\mu \mathrm{atm}$ and $902 \mu \mathrm{atm}$, respectively) $[62,66]$. Decreased expression of mitochondrion and oxidative metabolism genes are also observed under high $p \mathrm{CO}_{2}(720 \mu \mathrm{atm})$ in Mediterranean pteropods, including suppressed expression of the entire protein synthesis machinery [60]. In Antarctic pteropods, similar patterns are observed under $\mathrm{pH}$ stress after 7 days, including the downregulation of metabolic processes and genes associated with protein modifications [62]. Additionally, Antarctic pteropods downregulate lipid metabolism genes under low $\mathrm{pH}$ levels, presumably indicating differential energetic needs under acidified conditions. In Arctic copepods, there is no observable physiological response to low $\mathrm{pH}$ [66], however, there is a striking transcriptomic response with a genome-wide downregulation of genes, including those associated with fatty acid/lipid metabolism and energy.

Interestingly, many studies elaborated above are often not paired with physiological measurements that would further support metabolic depression, while those that do often find mixed results (Table 2). In blue mussels, there is an increase in whole organism oxygen consumption under high $p \mathrm{CO}_{2}$ levels (1120 and $\left.2400 \mu \mathrm{atm}\right)$ [102] despite a down-regulation of ATP-synthase subunits in mantle tissue at the exact same $p \mathrm{CO}_{2}$ levels [45]. Taken together, these studies suggest whole organism measurements do not necessarily reflect energetic changes in different tissues in response to reduced $\mathrm{pH}$, where in mantle tissue there is potentially a shift towards more anaerobic metabolism to support the demand for ATP [45]. In pearl oysters there is no significant effect of reduced $\mathrm{pH}(\mathrm{pH} 7.7$ and 7.4) on respiration rate [104] despite downregulation of metabolic pathways [50]. The authors instead report that maintaining acid-base equilibrium during $p \mathrm{CO}_{2}$ stress comes at a cost to biomineralization, since these animals show a reduction in net calcification rate [50]. In burrowing razor clams, Sinonovacula constricta, the depth at which clams burrow decreases with increasing $p \mathrm{CO}_{2}(549-3064 \mu \mathrm{atm})$ which is associated with decreases in oxygen consumption rates and $\mathrm{Ca}^{2+} / \mathrm{Mg}^{2+}$ ATPase activity [41]. Gene expression of TCA genes does not correspond with this pattern, however. Here, the authors conclude expression of the selected genes does not explain the differences in measured behavioral responses and physiological traits [41].

Studies that do report similar associations between downregulation of metabolic genes and physiological measurements include those in corals, brittle stars, snails and urchins. In A. millepora, photosynthetic capacity and light enhanced dark respiration are decreased under predicted ocean acidification scenarios, which is associated with downregulation of multiple metabolic pathways [25]. In brittle stars there is a significant reduction in resting metabolic rates at very low $\mathrm{pH}$ associated with deep burrows $(7.0 \mathrm{pH})$ which pairs with downregulation of metabolism related genes in arm tissue at both 7.3 and $7.0 \mathrm{pH}$ [72]. In S. purpuratus larvae there are only differences in oxygen consumption rates under high $p \mathrm{CO}_{2}(1100 \mu \mathrm{atm})$ when reared in warmer temperatures, an effect also seen in the regulation of histone transcripts, which the authors attribute to a depressed metabolism [82]. However, differences in larval oxygen consumption are evident as they develop into mature feeding larvae, eventually displaying increases in metabolic rate under elevated $p \mathrm{CO}_{2}(1318 \mu \mathrm{atm})$ [84]. Larval growth rate and metamorphosis at $6 \mathrm{~h}$ post hatching is delayed in the Atlantic slippersnail, Crepidula fornicata, under high $p \mathrm{CO}_{2}(1480 \mu \mathrm{atm})$, which coincides with an overall transcriptomic depression, including downregulation of multiple GO categories associated with metabolism and growth [64].

\section{Observation 2: Exposure to low pH conditions induces downregulation of calcification and skeletogenesis genes in some calcifying organisms, but not others}

Assessing the complexity of calcification regulation under $\mathrm{pH}$ stress in marine metazoans is often difficult due to the fact that many genes involved in these processes are presumably taxon-specific, and further, are unlikely to be well annotated. However, some calcifying organisms have well characterized calcification-related gene families and pathways, including echinoderms and mollusks. Calcification in echinoderms begins very early in development, in the planktonic late gastrula stage, where fully developed skeletal rods are observed in early 
pluteus larval stages. High $p \mathrm{CO}_{2}$ reduces overall body size, growth rate and skeletal development in early lifehistory stages of echinoderms [74, 77, 82, 84, 113], although adult pre-conditioning can have effects on larval responses to elevated $p \mathrm{CO}_{2}[109,114]$. Studies across four different species of sea urchins find decreases in expression of genes critical to calcification and skeletogenesis in early life-history stages, particularly those involved in binding and sequestering $\mathrm{Ca}^{2+}$ ions, including Msp130 [73, 74, 81, 109]. Across a developmental time-series of embryological and larval development in S. purpuratus, spicule matrix proteins were significantly downregulated under high $p \mathrm{CO}_{2}$ [84]. However, studies in urchins have revealed that the means by which calcification is regulated in response to $p \mathrm{CO}_{2}$ is complex and gene expression results have been mixed. When late gastrulae are exposed to variable $p \mathrm{CO}_{2}$ stress (800$1200 \mu \mathrm{atm})$ there is differential expression of many genes involved in skeletogenesis, while later stage larvae shows little to no differential expression of these genes [79]. However, when later stage echinoplutei are exposed to combinations of high temperature and $p \mathrm{CO}_{2}$ $(1100 \mu \mathrm{atm})$, there is differential expression of cytoskeletal genes and a spicule matrix protein [82], suggesting that regulation of skeletogenesis is a complicated process that responds to combinations of environmental effects. This study ultimately revealed that reductions in skeletogenesis in S. purpuratus echinoplutei are not a consequence of a depressed metabolism, but rather that high $p \mathrm{CO}_{2}$ inhibits the ability of these organisms to calcify [82]. It is not likely that these results are due to developmental delay as echinoplutei are sampled using developmental landmarks, and not with skeletal development [113]. Carbonic anhydrases (CAs) are often implied to be involved in biomineralization although there is often no signature of their differential expression in response to increased $p \mathrm{CO}_{2}$, or there is differential expression of only a small proportion of annotated CAs [79, 81, 110], suggesting that the role of CAs in mediating shifts to biomineralization in urchins is complex.

Many shelled mollusks play significant roles in their respective ecosystems as suspension filter feeders, as well as hold high economic value as fisheries and aquaculture species [115]. Therefore, there has been significant attention in how OA will impact these species in regards to growth, reproduction and maintenance of populations. Adult molluscan shells are typically composed of aragonite or calcite, rely on shell organic matrices and begin formation in early planktonic stages of development. Studies on the impact of OA on calcification of marine mollusks find the majority of adult responses to low $\mathrm{pH}$ are neutral in regards to calcification rates, although most of the remaining studies show negative effects [115]. Despite overall neutral effects in adults, the majority of studies examining early life-history stages show widespread negative effects, particularly on larval size, survival, developmental rates, metamorphosis and shell normality [115]. Variation in responses across mollusks may be due to varying capacities to regulate $\mathrm{pH}$ at the site of calcification, dissimilarities in the mineralogy of shells, and differences of protective organic layers between taxa [115]. Furthermore, studies have shown that an organism's shell minerology can change in response to OA $[116,117]$. Impacts of decreased $\mathrm{pH}$ on shelled mollusks has been well reviewed already [115], so here we will briefly highlight gene expression studies that have enhanced this work.

Studies of gene expression responses in shelled marine mollusks generally support observations gained in physiological studies (Table 3). In Pacific oysters, Crassostrea gigas, exposure to high $p \mathrm{CO}_{2}(\sim 1241 \mu \mathrm{atm})$ early in development results in a delay in shell formation and differential expression of extracellular matrix formation genes (i.e., shell matrix proteins), presumably involved in calcification [46]. In the planktonic mollusk, Heliconoides inflatus, all annotated calcification genes were significantly upregulated under mid-range $p \mathrm{CO}_{2}$ (617$720 \mu \mathrm{atm})$ including matrix proteins, metaloproteases, ctype lectins and mucins [60]. Reductions in net calcification rate in adult pearl oysters, Pinctada fucata, correspond to differential expression of calcium binding proteins, but not shell matrix proteins [50, 51]. In mantle tissue of blue mussels, there are decreases in expression of chitinase and calcium binding proteins at increasingly high $p \mathrm{CO}_{2}(385-4000 \mu \mathrm{atm})$, but not the majority of shell matrix proteins [45]. Therefore, it appears that high $p \mathrm{CO}_{2}$ impacts different aspects of shell production and growth across life-history stages, although levels of $p \mathrm{CO}_{2}$ across many of these studies can vary wildly. During shell formation in planktonic stages, expression of extracellular matrix genes, such as shell matrix proteins, become differentially regulated under high $p \mathrm{CO}_{2}$, while in adults, high $p \mathrm{CO}_{2}$ induced differential expression of genes regulating ion transport and acid-base homeostasis, including calcium binding [50], likely to maintain calcification.

The ability of reef-building corals to produce threedimensional skeletal structures drives the capacity for corals to provide resources to people as well as ecological goods and services [121]. OA threatens calcification and skeletal formation making it essential to understand the magnitude at which projected OA conditions will impact calcification in reef-building corals. A meta-analysis projected that coral calcification will decline $\sim 22 \%$ by the end of the century [122], although changes in calcification vary greatly between studies and species of coral, suggesting a scenario that will promote winners and losers. Therefore, recent studies have aimed 
Table 3 Impacts of high $\mathrm{CCO}_{2}$ on gene expression and calcification in marine invertebrate taxa. 'Calcification genes' is a broad term that encompasses any calcification or biomineralization processes as defined independently in each study, which includes acid-base regulation in some studies and not in others. Arrows denote the direction of the response. In instances with both arrows, this reflects either overall differential expression (genes being both up and down regulated), or conflicting results across studies or lifehistory stages. Dashes indicate a non-significant response. In studies where $p \mathrm{CO}_{2}$ was not calculated (or only calculated in some studies), pH values are given. It should be noted that calcification and gene expression measurements for a particular species may be confined to separate independent studies

\begin{tabular}{|c|c|c|c|c|c|c|}
\hline \multicolumn{7}{|l|}{ Calcification } \\
\hline Phylum & Species & $\begin{array}{l}\text { Calcification genes in } \\
\text { response to high } \\
\mathrm{pCO}_{2}\end{array}$ & $\begin{array}{c}\text { Calcification measured } \\
/ \text { response in high } \\
p \mathrm{CO}_{2}\end{array}$ & Method & $\begin{array}{l}\text { Range of } \\
\mathrm{pCO}_{2} \text { tested } \\
(\mu \mathrm{atm})\end{array}$ & Refs \\
\hline \multirow[t]{7}{*}{ Cnidaria } & $\begin{array}{l}\text { Acropora } \\
\text { gemmifera }\end{array}$ & $\downarrow$ & $Y / \downarrow$ & SEM & $389-1214$ & [28] \\
\hline & Acropora millepora & $\uparrow$ or $\downarrow$ & $Y / \downarrow$ & Change in weight & $325-1638$ & {$[21-26]$} \\
\hline & $\begin{array}{l}\text { Balanophyllia } \\
\text { elegans }\end{array}$ & $\uparrow$ or - & N & - & $785-2367$ & [30] \\
\hline & $\begin{array}{l}\text { Desmophyllum } \\
\text { dianthus }\end{array}$ & $\uparrow$ & Y/ - & Change in weight & 460-997 & [31] \\
\hline & $\begin{array}{l}\text { Pocillopora } \\
\text { damicornis }\end{array}$ & $\uparrow$ or - & $Y /-$ & Total alkalinity anomaly & $417-3879$ & $\begin{array}{l}{[32,33,99,} \\
100]\end{array}$ \\
\hline & Siderastrea siderea & - & $Y / \uparrow$ or $\downarrow$ & Change in weight & $280-2800$ & {$[34,118]$} \\
\hline & $\begin{array}{l}\text { Stylophora } \\
\text { pistillata }\end{array}$ & $\uparrow$ or $\downarrow$ & $Y / \uparrow$ or $\downarrow$ & Sr incorporation, SEM & pH:7.20-8.1 & {$[35,36]$} \\
\hline \multirow[t]{10}{*}{ Mollusca } & Crassostrea gigas & $\downarrow$ or - & $Y / \downarrow$ or - & $\begin{array}{c}\text { Cross polarized light microscopy/ } \\
\text { shell weight }\end{array}$ & 449-1515 & {$[46,48]$} \\
\hline & Crepidula fornicata & - & $Y / \downarrow$ & Shell length/growth rate & $504-1480$ & [64] \\
\hline & $\begin{array}{l}\text { Heliconoides } \\
\text { inflata }\end{array}$ & $\uparrow$ & $Y / \downarrow$ & ${ }^{45} \mathrm{Ca}$ uptake & $382-720$ & [60] \\
\hline & Limacina helicina & $\uparrow$ or $\downarrow$ & $\mathrm{N}$ & - & pH: 6.5-8.23 & [61] \\
\hline & $\begin{array}{l}\text { Limacina helicina } \\
\text { antarctica }\end{array}$ & $\uparrow$ or $\downarrow$ & N & - & $318-902$ & [62] \\
\hline & $\begin{array}{l}\text { Limacina } \\
\text { retroversa }\end{array}$ & $\uparrow$ & $\mathrm{Y} / \uparrow$ or - & Calcein staining/image analysis & $464-1177$ & [63] \\
\hline & $\begin{array}{l}\text { Mytilus } \\
\text { californianus }\end{array}$ & - & $Y / \downarrow$ & Larval shell length & $345-1411$ & [42] \\
\hline & Mytilus edulis & $\downarrow$ & $Y / \downarrow$ & Shell morphology & $385-4000$ & $\begin{array}{l}{[45,102,} \\
103]\end{array}$ \\
\hline & Pinctada fucata & $\uparrow$ or $\downarrow$ & $Y / \downarrow$ & $\begin{array}{l}\text { Shell length, weight, hardness, } \\
\text { calcium content, SEM, net } \\
\text { calcification rate, }\end{array}$ & $\mathrm{pH}: 7.4-8.1$ & {$[50-52,54]$} \\
\hline & $\begin{array}{l}\text { Saccostrea } \\
\text { glomerata }\end{array}$ & $\uparrow$ or $\downarrow$ & $Y / \downarrow$ & Shell length & $380-1329$ & $\begin{array}{l}{[55-57,} \\
105]\end{array}$ \\
\hline \multirow[t]{4}{*}{ Echinodermata } & Lytechinus pictus & $\downarrow$ & $Y / \downarrow$ & Skeletal morphology & 280-970 & [74] \\
\hline & $\begin{array}{l}\text { Paracentrotus } \\
\text { lividus }\end{array}$ & $\uparrow$ & $Y / \downarrow$ & Skeletal morphology $/^{45} \mathrm{Ca}$ uptake & $397-6590$ & [76] \\
\hline & $\begin{array}{l}\text { Strongylocentrotus } \\
\text { droebachiensis }\end{array}$ & - & $Y / \downarrow$ & Body size & $418-1145$ & [77] \\
\hline & $\begin{array}{l}\text { Strongylocentrotus } \\
\text { purpuratus }\end{array}$ & $\uparrow$ or $\downarrow$ & $Y / \downarrow$ & $\begin{array}{l}\text { Skeletal morphology /body size/ } \\
\text { Calcein pulse-chase experiments }\end{array}$ & 380-9556 & $\begin{array}{l}{[81,82,85,} \\
110,119, \\
120]\end{array}$ \\
\hline
\end{tabular}

to better understand mechanisms of calcification in reefbuilding corals in order to predict how changes in ocean $\mathrm{pH}$ will drive changes in the ecosystem services reefbuilding coral provide [123, 124]. For example, Porites spp. exhibit a decrease in skeletal density but not linear extension under future OA scenarios [124]. Many studies investigating gene expression responses to predicted OA scenarios have generally been complex across 
studies, life-history stages and species. Studies in A. millepora, have been performed across multiple contexts. When early recruits of $A$. millepora are exposed to high $p \mathrm{CO}_{2}(1000 \mathrm{ppm})$ during the onset of calcification, they exhibit both increased and decreased expression of many skeletal organic matrix proteins, known for their roles in $\mathrm{CaCO}_{3}$ deposition, and decreased expression of multiple CAs [21]. However, this response only appears under acute exposure to $p \mathrm{CO}_{2}$ stress (i.e., 3 days) as differential expression of these calcification-associated genes is not observed when juveniles are exposed directly after fertilization [22]. This highlights that early life-history stages of A. millepora may possess the capacity to acclimate to high $p \mathrm{CO}_{2}$ levels regarding their calcification ability. In adults of $A$. millepora, the results become more mixed. There was almost no differential regulation of extracellular matrix transcripts presumably involved in calcification after 28 days (at 1010-1350 $\mu$ atm), which is also found at the phenotype level as no change in growth or calcification was observed [24]. However, a follow up study with a longer exposure (5 weeks at $997 \mu \mathrm{atm})$ found complex patterns of gene expression in which calcium channels and transporters were upregulated under $\mathrm{pH}$ stress while bicarbonate transporters and CAs were downregulated [25]. Another study, which used adults of $A$. millepora exposed to elevated $p \mathrm{CO}_{2}$ (up to $1638 \mu \mathrm{atm}$ ) for 14 and 37 days, found no differential expression of candidate calcification genes including CAs, galaxins and a bicarbonate transporter [26]. However, an early qPCR study found differential expression of CAs under temperature and $p \mathrm{CO}_{2}(827 \mu \mathrm{atm})$ combined stress, modeled as a natural bleaching experiment, where temperature was manipulated through time in $A$. aspera [27]. In addition, A. millepora from volcanic $\mathrm{CO}_{2}$ seep environments experiencing chronic moderate to high $p \mathrm{CO}_{2}$ (624-998 $\left.\mu \mathrm{atm}\right)$ did not exhibit changes in calcification-related genes [23], suggesting calcification processes in corals are robust to changes in $\mathrm{pH}$. However, reduced levels of net calcification in A. millepora were found from the same volcanic sites, suggesting corals invest more energy in generating tissue biomass rather than skeletal growth when under acidified conditions [23, 111]. An opposite pattern was observed in temperate corals exposed to OA conditions (997 $\mu$ atm) for 8 months, in which there was no observed reduction in calcification or changes in respiration, yet there was an increased expression of enzymes presumed to play a role in skeletogenesis [31].

Exposure to low $\mathrm{pH}$, under-saturated conditions shows complex yet overall minimal impacts on calcification genes in A. millepora, however, there is variation in responses across coral taxa. In Pocillopora damicornis ex-

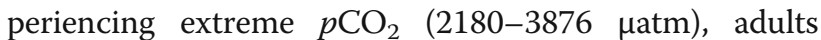
upregulated genes involved in calcification including bone morphogenic proteins (BMPs), CAs and galaxins after a 3-week low pH exposure [32]. In Siderastrea siderea, exposure to extreme $p \mathrm{CO}_{2}(2553 \mu \mathrm{atm})$ results in a slight reduction of calcification rate comparable to rates observed at pre-industrial $p \mathrm{CO}_{2}$ levels [118]. Gene expression associated with this effect includes differential expression of ion transport as opposed to calcificationassociated genes, although this effect was much smaller than effects of temperature [34]. The combination of these studies suggests that these reef-building corals are generally able to mitigate local changes in $p \mathrm{CO}_{2}$ by regulating the $\mathrm{pH}$ at the site of calcification using physiological mechanisms not associated with altering calcification directly. Interestingly, in an extreme experiment where Oculina patagonica and Madracis pharensis were exposed to $\mathrm{pH}$ levels of 7.3 and 7.6 for 12 months, polyps were found to completely dissolve their skeleton and disassociate from the colony [125]. When transferred back to ambient conditions, the soft bodied polyps re-calcified and began to reform colonies [125]. Although not necessarily ecologically relevant, this suggests the extreme capacity for plasticity in these coral species exposed to low $\mathrm{pH}$ conditions and suggests that coral have established mechanisms that trade-off skeletogenesis and calcification processes in favor of increased energy reserves and body size [125].

Finally, there is sometimes a disconnect between phenotypic measurements of calcification/growth and expression of genes presumed to be regulating these phenotypes (Table 3). In addition, methods in which to quantify changes in calcification vary substantially by taxon, making interpretations across studies complex (Table 3). Despite this, many studies find strong ties between calcification and gene expression signatures in organismal responses to OA, often reporting differential expression of calcium channels and transporters, bicarbonate transporters, CAs and skeletal organic matrix proteins, although this process is likely complex and regulated by numerous factors. Differential regulation of many of these proteins, along with modifications in ion transport mechanisms, can enable organisms to cope with $\mathrm{OA}$ by regulating internal $\mathrm{pH}$.

\section{Observation 3: High $\mathrm{pCO}_{2}$ exposure often induces the cellular stress response}

In marine metazoans, the cellular stress response (CSR) is a well characterized short term means of physiological tolerance to abiotic stress, but can also induce apoptosis, in which damaged cells are removed [126, 127]. Here, the heat shock response, the rapid up-regulation of molecular chaperones (heat shock proteins - HSPs), has been a key finding in many transcriptomic studies done in an OA context. Notably, the impact of OA has been investigated intensely in aquaculture species. The Sydney 
rock oyster, Saccostrea glomerata, has experienced decades of artificial selection for growth and disease resistance, which interestingly also corresponds to resilience against low $\mathrm{pH}[105,128,129]$. This resilient family of oysters shows increases in resting metabolic rates [105] and in genes associated with the CSR and immune system, such as HSPs, antioxidant enzymes glutathione Stransferases and $\mathrm{C} 1 \mathrm{q}$ domain proteins under ambient conditions $[55,56]$. These enzymes are then downregulated under transgenerational moderate $p \mathrm{CO}_{2}(625 \mu \mathrm{atm})$ when compared to a control family $[55,56]$. This suggests that constitutive expression of CSR genes may mitigate potential cell damage from reduced $\mathrm{pH}$ through the maintenance of cellular homeostasis. In another oyster species, C. gigas, planktonic stages of a population from China show a reduction in protein levels of HSPs under high $p \mathrm{CO}_{2}(\sim 1800 \mu \mathrm{atm})$ [130], while a population from the Pacific coast of the United States, exposed to a slightly lower $p \mathrm{CO}_{2}$ level $(\sim 1515 \mu \mathrm{atm})$ show no differential regulation of HSP transcripts [46], suggesting potentially different adaptation and acclimation strategies between populations. Antarctic pteropods also differentially regulate genes associated with the CSR at high $p \mathrm{CO}_{2}(902 \mu \mathrm{atm})$, including upregulation of HSP70 with decreases in other CSR components [62], while arctic copepods display downregulation of numerous molecular chaperones and genes associated with DNA repair and protein degradation [66], suggesting the CSR exhibits a complex response to low $\mathrm{pH}$. In S. purpuratus there is evidence that genes involved in the CSR are modulated under high $p \mathrm{CO}_{2}$; rearing larvae in moderate $(540 \mathrm{ppm})$ and high $p \mathrm{CO}_{2}(1020 \mathrm{ppm})$ resulted in a dose-dependent response involving downregulation of many genes associated with protein integrity, such as chaperones, and defense against oxidative stress [81]. Stress response genes were also downregulated in another urchin species, Lytechinus pictus under high $p \mathrm{CO}_{2}$ (970 ppm) [74]. Taken together, these studies imply that organisms experiencing high $p \mathrm{CO}_{2}$ could be more vulnerable to additional stressors because they may be compromised in their ability to mount an appropriate and robust CSR.

In contrast to planktonic stages of echinoderms, core HSP expression increased under both acute and prolonged exposure to high $p \mathrm{CO}_{2}(750 \mathrm{ppm})$ in A. millepora juveniles, suggesting a generic stress response [22]. In adult $A$. millepora, 28 day exposure to high and moderate $p \mathrm{CO}_{2}$ (700 and $\left.1100 \mu \mathrm{atm}\right)$ resulted in a downregulation of expression of HSPs [24], although there was an observed upregulation of genes associated with oxidative stress (catalase, FAD linked oxidase) and apoptosis (caspase, TRAFs, for example). A follow-up study on more genotypes of $A$. millepora and a 5 week $\mathrm{pH}$ stress exposure also found upregulation of oxidative stress related genes and genes associated with apoptosis, DNA repair and ubiquitination [25]. Finally, chronic $\mathrm{pH}$ stress corresponds to downregulation of HSPs in A. millepora [23] and upregulation of HSP70 in a cold water coral Desmophyllum dianthus [31]. Taken together, these studies suggest that in corals, acute exposure to low $\mathrm{pH}$ induced a stress response involving HSPs, but that expression pattern reverses after chronic exposure. Having reduced baseline levels of HSPs as a mechanism of tolerating low-term and chronic stress could prevent these organisms from mounting a robust stress response to additional stressors such as temperature, anoxia or eutrophication. Coral-specific responses to acidosis are likely complicated by the increase in reactive oxygen species (ROS) due to stress from their algal symbionts. In terms of reef-building corals and other obligate symbiotic marine organisms, it is critical to consider a holobiont perspective, as differences in gene expression changes in hosts under global stress scenarios could be reflective of variable interactions with algal symbionts and other associated microbiota. It is possible that differences in gene expression signatures across reef-building coral species and life-history stages could be due to differences in interactions between the host and stress response machinery of algal symbionts or other associated organisms.

\section{Observation 4: Ion transport and acid-base homeostasis is modulated in response to low $\mathrm{pH}$}

When marine metazoans are faced with influxes of $\mathrm{H}^{+}$ ions, membranes will strive to re-establish their acidbase equilibrium. This ion transport depends on key transporters including v-type $\mathrm{H}^{+}$ATPases, $\mathrm{Na}^{+} / \mathrm{H}^{+}$- and $\mathrm{Na}^{+}$dependent $\mathrm{Cl}^{-} / \mathrm{HCO}_{3}{ }^{-}$transporters [13]. Marine fishes are thought to be more robust to increases in $p \mathrm{CO}_{2}$ than invertebrates due to their high capacity to maintain acid-base homeostasis, although there is variability in sensitivities across fish taxa [131]. Atlantic cod, Gadus morhua, exposed to 3 different $p \mathrm{CO}_{2}$ levels (550 $\mu$ atm, $1200 \mu \mathrm{atm}, 2200 \mu \mathrm{atm})$ across 2 temperatures $\left(10{ }^{\circ} \mathrm{C}, 18^{\circ} \mathrm{C}\right)$ for 4 weeks showed temperaturedependent responses in multiple ion transport proteins, often with dose-dependent responses across $p \mathrm{CO}_{2}$ levels in gill tissue [91], while temperature had a stronger impact on expression of these same ion transport proteins in intestines [92]. These studies are further substantiated by protein levels of the same transport proteins. There is no evidence of differential regulation of $\mathrm{H}^{+}$transport genes in Acanthochromis polyacanthus juveniles after parental exposure to elevated $p \mathrm{CO}_{2}(754 \mu \mathrm{atm})$ although there is regulation of key circadian rhythm genes, which may tie into osmoregulation processes [88]. However, other fishes increase expression of acid-base homeostasis genes, indicative of higher sensitivity to elevated $p \mathrm{CO}_{2}$. 
Early life-history stages of medaka fish, Oryzias latipes, exhibit developmental delay and consistent upregulation of 2 key acid-base homeostasis genes in response to elevated $p \mathrm{CO}_{2}$ [93]. Upregulation of acid-base homeostasis genes is also evident after 7 day combined temperature and $p \mathrm{CO}_{2}(1000 \mu \mathrm{atm})$ exposure in Trematomus bernacchii [97] but not in Pagothenia borchgrevinki [94]. These transcriptomic studies reveal differences in response to elevated $p \mathrm{CO}_{2}$ across different fish species, similar to what is reported in physiological studies [131]. Although it should be noted that there are actually few studies that connect gene expression changes in ion transport with actual measurements of external $\mathrm{pH}$ and $\mathrm{HCO}_{3}{ }^{-}$levels (Table 4). Overall in fishes, although there are strong mechanisms to regulate acid-base homeostasis, future OA conditions are likely to elicit stress responses in some fishes.

Despite their presumed higher sensitivity to $p \mathrm{CO}_{2}$ than fish regarding acid-base homeostasis, marine invertebrates actually exhibit robust responses to elevated $p \mathrm{CO}_{2}$ as well. Early life-history stages of sea urchins regulated ion transport and acid-base homeostasis genes during development $[85,135,136]$, but nevertheless, low $\mathrm{pH}$ exposure also impacts expression of some genes involved with ion transport, mainly those involved in $\mathrm{Ca}^{2+}$ regulation, as discussed in detail in Observation 2 [74, $79,81]$. There was little to no differential expression of genes involved in transmembrane movement of $\mathrm{H}^{+}$ions when embryos and larvae were exposed to increased $p \mathrm{CO}_{2}$ [84], and across populations with different $\mathrm{pH}$ regimes [79] although there was significant downregulation of proton and $\mathrm{Na}^{+}$-dependent ion transporters in $[74,81]$ suggesting decreased capacity for ion transport under high $p \mathrm{CO}_{2}$. Measurements of internal midgut $\mathrm{pH}$ across various seawater $\mathrm{pH}$ levels showed stable gastric $\mathrm{pH}$ levels until seawater $\mathrm{pH}$ reached 7.22, at which time internal $\mathrm{pH}$ plummeted [85]. Overall, regulation of internal $\mathrm{pH}$ appears relatively stable in S. purpuratus, supporting the notion that these animals are able to internally modulate their cellular $\mathrm{pH}$ without adjusting their transcriptome [79, 81]. Acid-base homeostasis is altered more substantially in other echinoderms exposed to low $\mathrm{pH}$. In brittle stars, extracellular $\mathrm{pH}$ in coelmic cavities and body fluid $\mathrm{HCO}_{3}{ }^{-}$decreased and increased, respectively, when exposed to $\mathrm{pH} 7.6$ and 7.2 for 16 days, which corresponds to downregulation of some key ion regulation genes [72]. In general in calcifying organisms, ion transport and acid-base homeostasis are heavily intertwined with biomineralization and calcification mechanisms, which was previously discussed in more detail (Observation 2).

Acid-base homeostasis is disrupted in chitinous marine invertebrates as well. In spider crabs, Hyas araneus, body hemolymph $\mathrm{HCO}_{3}{ }^{-}$increased under intermediate $(1120 \mu \mathrm{atm})$ and high (1960 $\mu \mathrm{atm}) \quad p \mathrm{CO}_{2}$ while hemolymph $p \mathrm{CO}_{2}$ also increased in a dose-dependent manner, suggesting an inability to compensate to seawater with elevated $p \mathrm{CO}_{2}$ [71]. Expression of $\mathrm{v}$-type $\mathrm{H}^{+}$

Table 4 Impacts of high $\mathrm{pCO}_{2}$ on gene expression and acid-base homeostasis in marine invertebrate taxa. 'Acid-base homeostasis genes' is a broad term that encompasses any gene involved in proton $\left(\mathrm{H}^{+}\right)$and bicarbonate $\left(\mathrm{HCO}_{3}{ }^{-}\right)$transport as defined independently in each study. Arrows denote the direction of the response. In instances with both arrows, this reflects either overall differential expression (genes being both up and down regulated), or conflicting results across studies. Dashes indicate a nonsignificant response. It should be noted that physiological and gene expression measurements for a particular species may be confined to separate independent studies

\begin{tabular}{|c|c|c|c|c|c|c|}
\hline \multicolumn{7}{|c|}{ Acid-Base Homeostasis } \\
\hline Phylum & Species & $\begin{array}{l}\text { Acid-base homeostasis genes in } \\
\text { response to high } p \mathrm{CO}_{2}\end{array}$ & $\begin{array}{l}\text { External } p \mathrm{CO}_{2} / \\
\text { response in high } p \mathrm{CO}_{2}\end{array}$ & $\begin{array}{l}\mathrm{HCO}_{3}{ }^{-} \text {levels / } \\
\text { response in high } \\
p \mathrm{CO}_{2}\end{array}$ & $\begin{array}{l}\text { Range of } p \mathrm{CO}_{2} \\
\text { tested ( } \mu \text { atm) }\end{array}$ & Refs \\
\hline \multirow[t]{2}{*}{ Arthropoda } & Hyas araneus & $\uparrow$ or $\downarrow$ & $Y / \uparrow$ & $Y / \uparrow$ & $420-3300$ & [71] \\
\hline & Carcinus maenas & - & Y/ - & $Y /-$ & $40-440 \mathrm{~Pa}$ & {$[68,69]$} \\
\hline \multirow[t]{5}{*}{ Chordata } & $\begin{array}{l}\text { Acanthochromis } \\
\text { polyacanthus }\end{array}$ & - & $Y / \uparrow$ & $\mathrm{Y} / \uparrow$ & 414-1900 & $\begin{array}{l}{[88,89,} \\
132]\end{array}$ \\
\hline & Gadus morhua & $\uparrow$ or $\downarrow$ & N & $\mathrm{Y} / \uparrow$ & $550-2200$ & $\begin{array}{l}{[91,92,} \\
133]\end{array}$ \\
\hline & Oryzias latipes & $\uparrow$ & N & N & $393-7081$ & [93] \\
\hline & $\begin{array}{l}\text { Pagothenia } \\
\text { borchgrevinki }\end{array}$ & - & N & N & $427-1053$ & [94] \\
\hline & $\begin{array}{l}\text { Trematomus } \\
\text { bernacchii }\end{array}$ & $\uparrow$ & N & N & $430-1000$ & [97] \\
\hline \multirow[t]{2}{*}{ Echinodermata } & $\begin{array}{l}\text { Strongylocentrotus } \\
\text { purpuratus }\end{array}$ & $\downarrow$ or - & $Y / \downarrow$ or - & N & 380-9556 & $\begin{array}{l}{[81,85} \\
110,134]\end{array}$ \\
\hline & Amphiura filiformis & $\downarrow$ & $\mathrm{Y} / \downarrow(\mathrm{pH})$ & $Y / \uparrow$ & 492-6399 & [72] \\
\hline
\end{tabular}


ATPases and subunits of carbonic anhydrases were increased under elevated $p \mathrm{CO}_{2}$ [71], further substantiating the sensitivity of this species to OA conditions. In the green crab, Carcinus maenas, hemolymph $p \mathrm{CO}_{2}$ and $\mathrm{HCO}_{3}{ }^{-}$levels did not change after 7 days at $324 \mathrm{~Pa}$, although $\mathrm{K}+$ and ammonia concentrations significantly increased [68]. Expected acid-base homeostasis genes were not differentially expressed in this species, although additional candidates genes were revealed by this study [69]. Reef-building corals also modulate ion transport genes in response to different $\mathrm{pH}$ levels. Ion transport genes were not differentially regulated in juvenile A. millepora, with the exception of upregulation of $2 \mathrm{~T}$-type Calcium channels [21]. In adult A. millepora, exposure to $p \mathrm{CO}_{2}$ stress for 28 days resulted in differential regulation of membrane transporters [24]. This included upregulation of sodium and potassium transporters, $\mathrm{ABC}$ transporters and cell membrane receptors as well as a lipid transporter, suggesting elevated $p \mathrm{CO}_{2}$ levels may impact lipid configurations in cell membranes [24]. Under extreme $p \mathrm{CO}_{2}$, the coral Siderastraea siderea highly upregulates $\mathrm{H}^{+}$ion transport and ATP synthesis genes, suggesting this species works to regulate $\mathrm{pH}$ at the site of calcification under extreme $p \mathrm{CO}_{2}$ [34]. Adults of Pocillopora damicornis also upregulate genes associated with ion transport and regulation, including $\mathrm{Ca}^{2+}$ and $\mathrm{HCO}_{3}{ }^{-}$ transporters. However, at extremely low $\mathrm{pH}$ values this pattern was reversed [32]. Overall, corals harbor robust mechanisms to maintain acid-base homeostasis under OA stress with complex effects on calcification processes as detailed above in Observation 2. These studies combined suggest that ion transport and acid-base homeostasis are mechanisms at the forefront of responding to low $\mathrm{pH}$, and fine details of how these processes are regulated under varying $\mathrm{pH}$ regimes can be variable in regards to the magnitude of the stress, the life-history stage and the taxon.

\section{Observation 5: Neural functions and behavior are modulated by low $\mathrm{pH}$ through changes in ion transport mechanisms}

Organismal responses to OA shape larger-scale ecological processes through altering animal behaviors, including settlement, predation, foraging and habitat use [137]. Transcriptomic studies investigating mechanisms of these altered behaviors in response to OA are restricted to a few systems. While there are several reviews on the impacts of OA on fish behavior [137-142], we will briefly highlight the studies that link gene expression and physiological responses. In a variety of marine fish, high $p \mathrm{CO}_{2}$ can dampen responses to alarm and predator cues, behaviors that have large impacts on survival [137, 143, 144]. Physiological studies on this phenomenon suggest that this behavioral response is due to changes in acidbase ion transport that work to prevent acidosis, with downstream impacts on GABA function in the brain [145]. Complex transgenerational experiments have been performed in spiny damselfish, Acanthochromis polyacanthus, to parse out how plasticity in this behavioral response may be propagated across generations and how $\mathrm{OA}$ impacts brain function on a transcriptomic level. Individual fish that are sensitive or tolerant to OA, measured by their behavioral responses to predator alarm cues, were crossed with fish of similar phenotypes, and the progeny was reared at either control or high $p \mathrm{CO}_{2}$ conditions [88]. Gene expression in the brains of these fish suggest that offspring from tolerant parents have flexibility in their ion regulation and can shift their physiology to avoid maladaptive responses to high $p \mathrm{CO}_{2}$. A followup study also finds differential expression of genes associated with behaviors, ion regulation and GABA pathways when fish were exposed to high $p \mathrm{CO}_{2}$ acutely and throughout development, whereas these signatures returned to baseline levels when parents were previously exposed to high $p \mathrm{CO}_{2}$ [89]. Differential gene expression signals of transgenerational plasticity in response to $\mathrm{CO}_{2}$ varied between different parental genotypes, suggesting individual fish have different tolerances and sensitivities to how their brains regulate ion homeostasis, prevent acidosis and regulate GABA pathways [89]. European sea bass also show impaired sensory function under high $p \mathrm{CO}_{2}$ conditions, which was associated with differential expression of glutamate sensory pathways and genes associated with synaptic plasticity [144]. Taken together, these findings suggest that fish lose sensory acuity in their environment under high $p \mathrm{CO}_{2}$ conditions, an outcome that would have strong implications on fitness in situ.

OA also potentially impacts behaviors or neurological traits in planktonic mollusks. In Heliconoides inflatus pteropods that experienced acute exposures to three different $p \mathrm{CO}_{2}$ conditions, $22 \%$ of the differentially expressed genes were involved in nervous system functioning, including many ligand-gated ion channels, GABAergic, cholinergic and glutamatergic [60]. In contrast, an opposite pattern was found in Limacina helicina pteropods, in which there was a decrease in expression of many neural-associated genes, although these pteropods experienced a longer exposure to high $p \mathrm{CO}_{2}$ conditions [62]. There was, however, similar patterns of upregulation in genes associated with acetylcholine transport. These results reveal that low $\mathrm{pH}$ stress has the potential to impact a variety of behaviors in pteropods, which should be investigated as they could have profound effects on their biology and function within their respective ecosystems. 


\section{Observation 6: The transcriptomic response to low $\mathrm{pH}$ conditions vary by life-history stage}

OA effects on organisms and their transcriptomes can vary by life history stage. In general, early developmental stages (EDSs) are believed to be the most vulnerable times during the life-history of most marine organisms [146-148], and may act as the bottleneck that determines whether a species will be successful in the future [148-150]. Life-history strategies vary greatly across marine metazoan taxa, and must be carefully considered when examining transcriptomes and determining susceptibilities to OA. For instance, marine larvae are often planktonic, but some species undergo direct development in which there are no true larval stages or metamorphoses [151, 152]. OA will differentially impact benthic versus pelagic EDSs because they experience disparate habitats and thus selection pressures. Larvae may be either calcifying or non-calcifying, and may be planktotrophic (i.e., feeding) or lecithotrophic (i.e., nonfeeding), which may also impact their gene expression patterns and ability to cope with OA $[103,148,149$, 153]. Furthermore, the large expenditure of energy required for metamorphosis may place juvenile stages at increased risk to $\mathrm{pH}$ stress $[109,154]$ and negative impacts at earlier life stages may carry over into later stages, altering demography and distributions [155]. All of these factors are important considerations when designing and evaluating transcriptomic studies of EDSs in response to low $\mathrm{pH}$.

Developmental staging is critical in transcriptomics on EDSs [156]. A detailed developmental transcriptome can be a useful means by which to identify the molecular profiles of different stages and identify genes that are important during major developmental landmarks. It is also worth noting that low $\mathrm{pH}$ conditions can lead to delayed early development $[84,157]$. Thus it is vital to ensure the same developmental stages are compared regardless of different $\mathrm{pH}$ exposures. We recommend that EDSs are sampled based on observations of developmental progression rather than by a set number of hours postfertilization. Despite these considerations, understanding the effects of low $\mathrm{pH}$ on early development remain difficult largely due to intraspecific differences caused by genetic variation, variances in maternal investment, and phenotypic plasticity [158]. However, transcriptomics has been successfully used to investigate how EDSs respond to OA.

In general, studies investigating the effects of $\mathrm{OA}$ on the EDSs of sea urchins have found that low $\mathrm{pH}$ impacts genes involved in skeletogenesis, cellular stress response, ion regulation and transport, apoptosis, spicule matrix proteins, and metabolism [73, 76, 79, 81, 82, 110, 159]. Runcie et al. [77] used a quantitative genetic breeding design to examine the role of genetic variation in larval tolerance of $S$. droebachiensis larvae to low $\mathrm{pH}$, and found that changes in larval gene expression were more closely tied with differences of parentage than with differences of experimental $\mathrm{pH}$ treatments. In S. purpuratus, the exposure of adult female sea urchins to simulated upwelling conditions (i.e., high $p \mathrm{CO}_{2}$ in combination with low temperature) altered the transcriptomic response of gastrula stage embryos to high levels of $p \mathrm{CO}_{2}$ during early development [80]. These studies highlight that parental effects can greatly impact transcriptomic responses to OA in EDSs.

The transcriptomic response to OA has also been observed in fish EDSs. Fish can be more susceptible to low $\mathrm{pH}$ conditions during their early development [160], which may be due to the lack of fully developed organs that regulate ion exchange (e.g., gills, intestines, and kidneys) prior to reaching adulthood [93]. Transcriptomic analyses of the ricefish Oryzias latipes showed that embryos and hatchlings were more sensitive to OA than the adults, which the authors attribute to absence of fully developed ion regulatory epithelial tissues [93]. In contrast, larval fish of the European sea bass Dicentrarchus labrax exhibited no changes in gene expression across different $p \mathrm{CO}_{2}$ levels [90]. Even between two congeneric rockfish, Hamilton et al. [96] found that the transcriptomic response of juvenile rockfish to high $p \mathrm{CO}_{2}$ varied by species, indicating that fish sensitivity to OA during early development is largely species-specific. Lastly, parental effects can influence the gene expression patterns of fish during early development. For instance, in the damselfish Acanthochromis polyacanthus, the expression of genes related to glucose regulation and histone variants varied between offspring of adults that were behaviorally tolerant or sensitive to high $p \mathrm{CO}_{2}$ [88]. Furthermore, transgenerational exposure to high $\mathrm{CO}_{2}$ conditions altered offspring gene expression to baseline levels that were similar to those found in control fish raised under present-day $\mathrm{CO}_{2}$ conditions. Thus, the transcriptomic response of juvenile offspring to acidified conditions were shown to vary by both parental phenotype and by parental exposure to high $p \mathrm{CO}_{2}$ [88].

Unlike other systems, the early life-history stages of reef-building corals may be relatively resilient to OA when compared to their adult counterparts. This may be because coral larvae do not actively undergo calcification processes; the expression of genes related to biomineralization increases upon settlement [161]. For example, there were greater changes in gene expression of adult $P$. damicornis under high $p \mathrm{CO}_{2}$, particularly of genes related to calcification processes [32], than of larval $P$. damicornis subjected to acute high $p \mathrm{CO}_{2}$ exposures [33]. Specifically, Rivest et al. [33] found a stronger transcriptomic response in the algal symbionts of $P$. damicornis than in the larvae themselves. In other reef-building 
coral species, symbiosis is established horizontally, typically after metamorphosis and during early skeletal formation. Thus, one benefit of examining EDSs of horizontally transmitting corals is that their transcriptomic responses are not confounded by obligate algal symbiosis [21]. Acute exposure to low $\mathrm{pH}$ conditions impacted newly settled coral polyps by altering expression patterns of genes related to skeletal organic matrix proteins involved in calcium carbonate deposition processes [21]. However, given a longer exposure period, juvenile coral polyps appeared to acclimate to elevated $p \mathrm{CO}_{2}$ levels via an increase in expression of antiapoptotic genes [22]. Overall, while EDSs are thought to be more vulnerable than adults, transcriptomic evidence supports that coral EDSs may be surprisingly robust to OA.

\section{Observation 7: OA interacts with other abiotic factors in a multi-stressor context}

Changes in ocean $\mathrm{pH}$ can naturally vary in tandem with other environmental factors. For instance, upwelling brings waters characterized by a combination of low $\mathrm{pH}$ levels, low temperatures, and low oxygen concentrations [162, 163]. In systems dominated by benthic algae and macrophytes, biotic processes such as photosynthesis can result in high positive correlations between $\mathrm{pH}$ and oxygen $[164,165]$. Natural variations in ocean conditions, all of which vary greatly by habitat and region $[166,167]$, will be further complicated by anthropogenic impacts, such as increasing absorption of atmospheric $\mathrm{CO}_{2}$ into the open ocean [167] or coastal nutrient enrichment [168]. As climate change continues, OA is not expected to occur in isolation; other environmental stressors are anticipated to intensify in the future as well [169-171]. Because factors such as ocean $\mathrm{pH}$, temperature, salinity, and oxygen levels are predicted to change, often simultaneously, a multistressor approach may be required to accurately predict organismal responses to future marine environments [150, 172].

Studies that have used transcriptomics to investigate $\mathrm{OA}$ in a multistressor context have focused primarily on temperature as an additional stressor. O'Donnell et al. [75] subjected larvae of the red sea urchin Mesocentrotus franciscanus raised under different $p \mathrm{CO}_{2}$ levels to acute temperature treatments to determine how $\mathrm{OA}$ affected the thermal stress response. This study found that following a one-hour exposure to elevated temperatures, larvae raised under elevated $p \mathrm{CO}_{2}$ showed lower expression of the molecular chaperone HSP70. HSP70, which plays an important role in cellular defense, is controlled by a temperature sensitive promoter. Thus, a measured decrease in expression of HSP70 as a result of elevated $p \mathrm{CO}_{2}$ exposure suggests that larvae exposed to lower $\mathrm{pH}$ conditions may be more vulnerable to heat stress [75].
Other studies examined the transcriptomic response of organisms exposed to low $\mathrm{pH}$ and temperature stress at the same time. Simultaneous exposure to elevated $p \mathrm{CO}_{2}$ levels and temperatures has been shown to induce a transcriptomic stress response in coral and their symbionts [27, 29, 33], oysters [50-52, 56], crabs [71], sea urchins [82], and fishes [91, 94, 97]. These studies have examined temperature in the context of ocean warming, in which temperatures are elevated relative to average, ambient temperatures. While this is certainly pertinent given rising global temperatures, it is also worth noting that the intensity and duration of upwelling events are expected to increase in the future [173]. As such, it is also relevant to examine how combinations of high $p \mathrm{CO}_{2}$ with low temperatures, such as during upwelling events, will affect the transcriptome.

Other studies have investigated the combined effect of $\mathrm{OA}$ and chemical contamination on gene expression, particularly in bivalve species that inhabit coastal regions impacted by pollution [40, 47]. The negative immunosuppressive effect of cadmium exposure on the oyster $C$. gigas was intensified by simultaneous exposure to acidified conditions [47]. Specifically, the combined exposure of low $\mathrm{pH}$ and cadmium led to an increase in expression of genes involved in the Toll-like receptor (TLR) signaling pathway and immune factors, tumor necrosis factor (TNF) and integrin beta-1B. In the clam Ruditapes philippinarum, low $\mathrm{pH}$ affected the toxicity of pharmaceutical drugs, altering the expression of genes related to metabolism, neurotransmission, and the drug mode of action [40]. Overall, these studies show that OA can interact with contaminants, altering toxicity and organism sensitivity to different chemical pollutants.

In general, there are three major classifications of stressor interactions: (1) additive effects in which the combined effect is equal to the sum of the individual effects, (2) synergistic effects in which the combined effect is greater than the sum of the individual effects, and (3) antagonistic effects in which the combined effect is less than the sum of the individual effects [174, 175]. Most studies using transcriptomics to investigate multiple stressors including acidification have found evidence of synergistic effects [27, 29, 47, 49, 52, 94, 97], although there are several exceptions to this. Padilla-Gamino et al. [82] found that elevated $p \mathrm{CO}_{2}$ and temperature had an additive effect on S. purpuratus larvae, and concluded that ocean warming would not exacerbate the impaired skeletal growth caused by increased $p \mathrm{CO}_{2}$. In the Sydney rock oyster, S. glomerata, Goncalves et al. [56] found that the effects of $p \mathrm{CO}_{2}$ and temperature were neither additive nor synergistic, and were potentially antagonistic, in which temperature may have offset the effects of elevated $p \mathrm{CO}_{2}$. Adverse effects of $\mathrm{OA}$ on organism growth and calcification have been shown to be 
ameliorated by warming in some species $[150,168,176$, 177], although there is little evidence of this at the transcriptomic level. In contrast, Davies et al. [34] reported that the coral $S$. siderea was more negatively affected by high temperature than low $\mathrm{pH}$, with transcriptomic patterns providing evidence of cellular shutdown under warming conditions while there was potential for acclimation to OA (i.e., an upregulation of genes related to ion transport).

While studies have examined the transcriptomic response of combined temperature or chemical pollutant stress with $\mathrm{OA}$, environmental variables such as oxygen levels or salinity are largely absent from transcriptomic multi-stressor studies. Furthermore, nearly all studies are limited to two stressors. This is understandable, as manipulating more than two factors can lead to highly complex experimental design and difficult data interpretation. The challenge lies in choosing the appropriate combination of stressors that is ecologically relevant and accurately reflects what organisms are likely to experience in their current and future environments. Field experiments performed in situ allow for the full combination of environmental factors that organisms are experiencing in nature. One such study by Chapman and colleagues examined gene expression patterns in oysters across several environmental factors, including $\mathrm{pH}$, temperature, salinity, dissolved oxygen, turbidity, chlorophyll a, ammonium levels, and metal and organic contaminants [49]. Changes in the transcriptome were primarily controlled by environmental $\mathrm{pH}$ and temperature, although salinity and dissolved oxygen also explained some patterns in the transcriptome. Combined low $\mathrm{pH}$ and high temperature stress decreased expression of genes involved in protein synthesis and cell growth, and increased expression of genes related to ATP production (i.e., mitochondrial oxidative phosphorylation.) Metal and organic contaminants, however, had a minimal impact of the observed gene expression patterns. Overall, this study examined how transcriptome patterns changed with respect to individual stressors as well as combinations of a multitude of stressors, providing important insight into how organisms respond to their highly variable and complex environments.

\section{Evolutionary potential to adapt to $O A$}

Many early ocean acidification studies selected experimental $\mathrm{pH}$ levels based on IPCC (Intergovernmental Panel on Climate Change) projections for atmospheric concentrations of $\mathrm{CO}_{2}$ or average surface ocean $\mathrm{pH}$ levels predicted for the year 2100. However, as we learned more about in situ $\mathrm{pH}$ in coastal oceans (Hofmann et al. 2011), these $\mathrm{pH}$ levels were often not ecologically relevant for the range of marine ecosystems under study. Early OA studies often exposed organisms to high $p \mathrm{CO}_{2}$ levels that are likely ecologically unlikely, or did not include natural dynamics of $p \mathrm{CO}_{2}$ fluctuation, thus complicating the interpretation of organismal response to near future acidification projections. In addition, awareness started to grow regarding the influence of multiple stressors [178]. For instance, other anthropogenic effects (e.g., nutrient enrichment) contribute to decreases in $\mathrm{pH}$, particularly near heavily populated coastal areas $[179,180]$. The culmination of these anthropogenic impacts act in combination with natural variations in ocean $\mathrm{pH}$, resulting in $\mathrm{pH}$ conditions that can vary dramatically by habitat and location $[166,167]$. In order to understand adaptive potential, it is critical to frame studies within an organism's natural environment, especially through time. Although these early studies were informative, particularly in regards to mechanisms enabling regulation of internal $\mathrm{pH}$ and calcification, we sometimes missed the opportunity to explore plasticity, and the potential for organisms to adapt to future ocean $\mathrm{pH}$ values. Many calcifying organisms have been exposed to fluctuations in ocean $\mathrm{pH}$ throughout their evolutionary history, however, it is yet to be determined if organisms can evolve rapidly enough to combat the quick pace of OA since the Industrial Revolution. Strategies to investigate adaptive potential to OA include 1) comparative population studies that examine natural variation in stress response phenotypes, and the genetic basis behind this variation, across landscapes that vary in $\mathrm{pH}, 2$ ) studies that examine organismal responses to pre-industrial ocean $\mathrm{pH}$ as a treatment in short term response studies, 3) studies that examine adaptive responses to $\mathrm{pH}$ across multiple generations and 4) studies that incorporate environmental sensor data to inform experimental conditions based on the natural variability within the environment.

Comparative population studies have been performed in S. purpuratus inhabiting the California Current System, where variation in exposure to $\mathrm{pH}$ is likely to drive local adaptation in sensitivity to OA [78, 87]. In a common garden approach that investigated natural variation in gene expression of larvae from populations experiencing varying frequencies of low $\mathrm{pH}$ episodes, along with differences in temperature and oxygen, Evans et al. [78] found that larvae from populations experiencing more frequent low $\mathrm{pH}$ episodes upregulated key metabolic processes normally downregulated under $\mathrm{pH}$ stress. Therefore, it is likely that when S. purpuratus populations are chronically exposed to higher frequencies of low $\mathrm{pH}$, as in the northern populations, they have adapted by constitutively expressing genes that enable higher ATP production, a pattern also found in a comparative population study in eastern oysters, C. virginica [49]. In another comparative study of S. purpuratus populations, Pespeni et al. [181] used a common garden 
approach and found that genes involved in carbohydrate and lipid metabolism were under selection, providing further evidence that chronic responses to low $\mathrm{pH}$ involve generating higher energy stores in the form of carbohydrates, lipids and ATP. Additional evidence for local adaptation to variable $\mathrm{pH}$ regimes is evident when examining differences in biomineralization genes; adult urchins from southern populations overexpress biomineralization genes when exposed to lower $\mathrm{pH}$ regimes for 3 years [87].

$\mathrm{CO}_{2}$ seep environments provide a window into community and organismal responses to chronically high $p \mathrm{CO}_{2}$ and give opportunities to observe acclimatization and adaptation in a natural environment [182, 183]. Volcanic $\mathrm{CO}_{2}$ seep sites in Papua New Guinea (PNG) and the Mediterranean exhibit differences in community composition and variation in taxon representation, suggesting that some species are intolerant of these extreme environments while some have found mechanisms of acclimation or adaptation [7, 184]. In addition, there are several seep environments in each region, providing site replication to further substantiate observations in these unique environments. While physiological studies of organisms inhabiting $\mathrm{CO}_{2}$ seeps have begun to unravel the effects of chronic $p \mathrm{CO}_{2}$ stress $[111,185]$, only one study to date has investigated differences in the transcriptome between individuals living within the seep environments and individuals within sites directly nearby the seeps but with ambient conditions [23], although additional proteomic investigations have also been performed [186]. In the transcriptomic study, gene expression of A. millepora individuals and their algal symbionts from two $\mathrm{CO}_{2}$ seeps and nearby control sites revealed a core expression response associated with individuals living in those extreme environments [23]. This response was associated with differential expression of very few genes, but included downregulation of molecular chaperones and alterations in fatty-acid lipid metabolism from individuals in the seep sites. This study highlights that chronic low $\mathrm{pH}$ environments generate very different gene expression responses than acute exposures typical of laboratory experiments.

Other studies in reef-building corals have examined organismal responses to pre-industrial ocean $\mathrm{pH}$ levels. Siderastrea siderea shows reductions in calcification rates at pre-industrial $p \mathrm{CO}_{2}$ levels $(324 \mu \mathrm{atm})$ that mirror those at extreme $p \mathrm{CO}_{2}(>2500 \mu \mathrm{atm})$, however, there was minimal changes in the transcriptome associated with the preindustrial levels [34]. In A. millepora, increased rates of photosynthesis were observed when corals were exposed to pre-industrial $p \mathrm{CO}_{2}$ levels [25]. In addition, there appears to be a complex regulation of metabolic processes when corals were exposed to 5 weeks of pre-industrial $p \mathrm{CO}_{2}$ levels, such as the upregulation of cell cycle-related genes and glycolysis with a downregulation of Calvin cycle genes [25]. These results together suggest that $S$. siderea may be better adapted to pre-industrial conditions and are still in the process of adapting to current $p \mathrm{CO}_{2}$ levels. If there does exist this lag in evolutionary responses to the environment, it could be further evidence that although corals can evolve and adapt to changes in $p \mathrm{CO}_{2}$, the rate at which $p \mathrm{CO}_{2}$ levels in the ocean are increasing may be faster than the rate at which these corals can respond.

In addition to $\mathrm{pH}$ levels, exposure frequency and duration are important considerations in transcriptomic studies investigating adaptive capacity to OA. This includes incorporating fluctuating and variable $\mathrm{pH}$ conditions that occur in the natural environment into experimental designs. There is a great degree of natural variability in $p \mathrm{CO}_{2}$ across marine ecosystems [187], something the research community has documented at high spatiotemporal resolution through use of autonomous $\mathrm{pH}$ sensors. Such considerations are particularly relevant when reflecting upon when during an organism's life cycle exposure to low $\mathrm{pH}$ occurs as well as the length of a species' generation time. Many transcriptomic studies in marine systems that have examined differences in exposure frequency and duration have been rooted in toxicology $[156,188,189]$. Here, however, we briefly highlight a few examples of OA-focused transcriptomic studies that have tailored their experimental design to match the ecology of their study system. Transcriptomic studies that fail to frame their investigations within an ecologically relevant context risk inaccurately predicting how marine organisms respond to low $\mathrm{pH}$ in nature.

Evans et al. [79] measured the naturally variable conditions of a highly dynamic intertidal habitat that experiences regular upwelling events. After hypothesizing that these conditions may have led to local adaptation to low $\mathrm{pH}$ regimes, Evans and colleagues used their field measurements as well as future $\mathrm{pH}$ levels predicted for their study area [190] to inform the experimental $\mathrm{pH}$ conditions under which they examined the transcriptomic response of purple sea urchin larvae. In a polar habitat, Johnson and Hofmann [62] used observations made with autonomous pH sensors in McMurdo Sound, Antarctica [191] to select present-day and predicted future seasonal $\mathrm{pH}$ treatments. Applying these $\mathrm{pH}$ values, the authors compared shorter and longer-term acclimation to low $\mathrm{pH}$ levels in Antarctic pteropods by examining changes in gene expression [62]. In a study by Maas and colleagues [58], knowledge of their study organism's behavior and natural environment was used to inform the experimental design. Laboratory $\mathrm{CO}_{2}$ conditions were manipulated to mimic levels that were experienced during diel vertical migrations of the thecosome pteropod 
Clio pyramidata to examine its short-term transcriptomic response of elevated $\mathrm{CO}_{2}$ [58]. Studies such as these underscore the functionality of understanding how organism ecology can vary between different marine systems and the importance of taking this into account to accurately assess transcriptomic responses to $\mathrm{pH}$.

\section{Caveats and considerations}

The use of transcriptomic studies in understanding molecular and physiological responses to stress has been fundamental in identifying key processes and pathways modulated under OA stress. However, the utility of transcriptomics still comes with caveats. In particular, very few transcriptomic studies are validated with proteomic or enzymatic activity data, although see [57, 83, 88]. There can be a disconnect between changes in gene expression and protein levels, especially in regard to timescales of regulatory responses in the cell and when stress occurs during early development, which may favor different compensatory mechanisms to combat stress as to not disrupt developmental processes. In addition, it is possible that other mechanisms may modulate changes in phenotypes in response to stress, such as posttranslational modifications, epigenetic processes and transposon activity. Regardless, the ease and relative cost-effectiveness of transcriptomics have allowed the organismal OA community to reveal broad consistent patterns across a wide variety of taxa (Table 1).

Two of the major caveats in comparing transcriptomic studies are defining gene function and assigning appropriate orthologs. In reality, interpreting functions of specific genes in many of the marine metazoans is based on strong, perhaps unfounded, underlying assumptions based on conserved gene function and orthology. There are exceptions to this, such as S. purpuratus, for which many gene annotations have been manually curated and functions during development described in depth [192, 193]. Therefore, functional understanding of gene expression patterns in many non-model systems is best carried out using broad functional groups (Gene Ontology Analysis) or by clustering groups of genes with similar patterns in a manner that is unbiased to gene function, such as Weighted Gene Co-Expression Network Analysis (WGCNA) [194], as suggested in a recent review [195]. This analysis is also recommended as it is evident that there are differences in bioinformatic pipelines used to identify candidate genes/genes of interest, as studies often choose to discuss candidate genes based on prior biases regarding their system of interest. While outside the scope of this review, there are other detailed reviews examining different bioinformatic methodologies to approach gene expression and transcriptomic data [195-198].

\section{Conclusions}

In this review we have highlighted broad transcriptomic patterns expressed by marine metazoans in response to OA. The studies reviewed here have laid a strong foundation to further explore mechanisms of organismal responses to OA. Looking forward, it is critical to build from these studies to gain a stronger picture of how transcriptomics can inform the complexity of organismenvironment interactions. Future work should focus on more mechanistic explanations through functional genetic studies that characterize gene function in an ecologically relevant context. In addition, transcriptomics should be more often compared with high throughput examinations of epigenetic marks, post-translational modifications, transposon activity, metabolomics and interactions with microbiomes/symbionts, all of which have the power to modulate phenotypes in concert with transcriptomic changes. The wealth of available transcriptomic data lends itself to comparative transcriptomics aimed to identify biomarkers of organismal health and stress, which could be used as tools in management and conservation of threatened ocean systems. Further, future studies should better integrate natural environmental fluctuations. Despite some restrictions and caveats of comparative transcriptomics, it remains a valuable approach to investigate pressing zoological issues such as $\mathrm{OA}$, and for example, the emergence of marine heatwaves $[199,200]$. Overall, comparative transcriptomics will continue to play a strong role in studying the response of marine metazoans to ocean change and opens up avenues of future research.

\section{Abbreviations \\ CA: Carbonic anhydrase; CSR: Cellular stress response; EDS: Early developmental stage; FAD: Flavin adenine dinucleotide; \\ GAPDH: Glyceraldehyde 3-phosphate dehydrogenase; HSP: Heat shock protein; $\mathrm{OA}$ : Ocean acidification; $\mathrm{pCO}_{2}$ : Partial pressure of carbon dioxide; PNG: Papua New Guinea; qPCR: quantitative polymerase chain reaction; RNA- Seq: RNA sequencing; ROS: Reactive oxygen species; SEM: Scanning electron microscopy; TRAF: Tumor necrosis factor receptor associated factor}

\section{Acknowledgements \\ We would like to thank the additional members of the Hofmann lab and anonymous reviewers for discussion and comments on this manuscript.}

\section{Authors' contributions}

All authors contributed to writing and approved the final manuscript.

\section{Funding}

During the preparation of this manuscript, the authors were partially supported by funds from a U.S. National Science Foundation award (IOS1656262) to G.E.H. In addition, J.M.W. was supported by an NSF Graduate Research Fellowship under Grant No. 1650114.

\section{Availability of data and materials}

The data presented in this manuscript are extracted from published literature.

Ethics approval and consent to participate Not applicable. 


\section{Consent for publication}

Not applicable.

\section{Competing interests}

The authors declare that they have no competing interests.

\section{Author details}

'Department of Ecology, Evolution and Marine Biology, University of California Santa Barbara, Santa Barbara, CA 93106, USA. ²Department of Biological Sciences, Auburn University, Auburn, AL 36849, USA. ${ }^{3}$ Present address: Department of Biological Sciences, Florida International University, North Miami, FL 33181, USA.

Received: 18 December 2018 Accepted: 6 January 2020

Published online: 17 February 2020

\section{References}

1. Kleypas JA, Buddemeier RW, Archer D, Gattuso J, Langdon C, Opdyke BN. Geochemical consequences of increased atmospheric carbon dioxide on coral reefs. Science. 1999;284:118-20.

2. Riebesell U, Zondervan I, Rost B, Tortell PD, Zeebe RE, Morel FMM. Reduced calcication of marine plankton in response to increased atmospheric $\mathrm{CO}_{2}$. Nature. 2000;407:364-7.

3. Kurihara $\mathrm{H}$, Shimode $\mathrm{S}$, Shirayama $\mathrm{Y}$. Sub-lethal effects of elevated concentration of $\mathrm{CO}_{2}$ on planktonic copepods and sea urchins. J Oceanogr. 2004;60:743-50

4. Caldeira K, Wickett ME. Anthropogenic carbon and ocean pH. Nature. 2003; 425:365.

5. Caldeira K, Wickett M. Ocean model predictions of chemistry changes from carbon dioxide emissions to the atmosphere and ocean. J Geophys Res C Ocean. 2005;110:1-12.

6. Feely RA, Sabine CL, Lee K, Berelson W, Kleypas J, Fabry VJ, et al. Impact of anthropogenic $\mathrm{CO}_{2}$ on the $\mathrm{CaCO}_{3}$ system in the oceans. Science. 2004;305: 362-6.

7. Teixidó N, Gambi MC, Parravacini V, Kroeker K, Micheli F, Villéger S, et al. Functional biodiversity loss along natural $\mathrm{CO}_{2}$ gradients. Nat Commun. 2018;9:5149.

8. Newell RIE. Ecosystem influences of natural and cultivated populations of suspension-feeding bivalve molluscs: a review. J Shellfish Res. 2004;23:51-61.

9. Kroeker KJ, Kordas RL, Crim RN, Singh GG. Meta-analysis reveals negative yet variable effects of ocean acidification on marine organisms. Ecol Lett. 2010; 13:1419-34

10. Hofmann GE, Barry JP, Edmunds PJ, Gates RD, Hutchins DA, Klinger T, et al The effect of ocean acidification on calcifying organisms in marine ecosystems: an organism-to-ecosystem perspective. Annu Rev Ecol Evol Syst. 2010;41:127-47.

11. Fabry VJ, Seibel BA, Feely RA, Orr JC. Impacts of ocean acidification on marine fauna and ecosystem processes. ICES J Mar Sci. 2008;65:414-32.

12. Hoegh-Guldberg O, Mumby PJ, Hooten AJ, Steneck RS, Greenfield P, Gomez $E$, et al. Coral reefs under rapid climate change and ocean acidification. Science. 2007:318:1737-42.

13. Portner $\mathrm{HO}$, Langenbuch $\mathrm{M}$, Reipschlager A. Biological impact of elevated ocean $\mathrm{CO}_{2}$ concentrations: lessons from animal physiology and earth history. J Oceanogr. 2004:60:705-18.

14. Barton A, Waldbusser G, Feely R, Weisberg S, Newton J, Hales B, et al. Impacts of coastal acidification on the Pacific northwest shellfish industry and adaptation strategies implemented in response. Oceanography. 2015; 25:146-59.

15. Adelsman $\mathrm{H}$, Binder LW. Washington state blue ribbon panel on ocean acidification (2012): ocean acidification: from knowledge to action. Olympia, Washington: Washington State's strategic response; 2012.

16. Mangi SC, Lee J, Pinnegar JK, Law RJ, Tyllianakis E, Birchenough SNR. The economic impacts of ocean acidification on shellfish fisheries and aquaculture in the United Kingdom. Environ Sci Pol. 2018;86:95-105.

17. Vizzini S, Martínez-Crego B, Andolina C, Massa-Gallucci A, Connell SD, Gambi MC. Ocean acidification as a driver of community simplification via the collapse of higher-order and rise of lower-order consumers. Sci Rep. 2017:7:1-10.

18. Alsterberg C, Eklof JS, Gamfeldt L, Havenhand JN, Sundback K. Consumers mediate the effects of experimental ocean acidification and warming on primary producers. Proc Natl Acad Sci. 2013;110:8603-8.
19. Kroeker KJ, Micheli F, Gambi MC, Martz TR. Divergent ecosystem responses within a benthic marine community to ocean acidification. Proc Natl Acad Sci. 2011;108:14515-20.

20. DeBiasse MB, Kelly MW. Plastic and evolved responses to global change: what can we learn from comparative transcriptomics? J Hered. 2016;107:71-81.

21. Moya A, Huisman L, Ball EE, Hayward DC, Grasso LC, Chua CM, et al. Whole transcriptome analysis of the coral Acropora millepora reveals complex responses to $\mathrm{CO}_{2}$-driven acidification during the initiation of calcification. Mol Ecol. 2012;21:2440-54.

22. Moya A, Huisman L, Forêt S, Gattuso JP, Hayward DC, Ball EE, et al. Rapid acclimation of juvenile corals to $\mathrm{CO}_{2}$-mediated acidification by upregulation of heat shock protein and BCl-2 genes. Mol Ecol. 2015;24:438-52.

23. Kenkel CD, Moya A, Strahl J, Humphrey C, Bay LK. Functional genomic analysis of corals from natural $\mathrm{CO}_{2}$-seeps reveals core molecular responses involved in acclimatization to ocean acidification. Glob Chang Biol. 2018;24: $158-71$

24. Kaniewska P, Campbell PR, Kline DI, Rodriguez-Lanetty M, Miller DJ, Dove S, et al. Major cellular and physiological impacts of ocean acidification on a reef building coral. PLoS One. 2012;7:e34659.

25. Kaniewska P, Chan CKK, Kline D, Ling EYS, Rosic N, Edwards D, et al. Transcriptomic changes in coral holobionts provide insights into physiological challenges of future climate and ocean change. PLoS One. 2015;10:e0139223.

26. Rocker MM, Noonan S, Humphrey C, Moya A, Willis BL, Bay LK. Expression of calcification and metabolism-related genes in response to elevated $p \mathrm{CO}_{2}$ and temperature in the reef-building coral Acropora millepora. Mar GenomicsElsevier BV. 2015;24:313-8.

27. Ogawa D, Bobeszko T, Ainsworth T, Leggat $W$. The combined effects of temperature and $\mathrm{CO}_{2}$ lead to altered gene expression in Acropora aspera. Coral Reefs. 2013;32:895-907.

28. Yuan $X$, Yuan $T$, Huang $\mathrm{H}$, Jiang $\mathrm{L}$, Zhou W, Liu S. Elevated $\mathrm{CO}_{2}$ delays the early development of scleractinian coral Acropora gemmifera. Sci RepSpringer US. 2018;8:1-10.

29. Maor-Landaw K, Waldman Ben-Asher H, Karako-Lampert S, Salmon-Divon M, Prada F, Caroselli E, et al. Mediterranean versus Red Sea corals facing climate change, a transcriptome analysis. Sci RepNature Publishing Group. 2017;7:3-10.

30. Griffiths JS, Pan TF, Kelly MW. Differential responses to ocean acidification between populations of Balanophyllia elegans corals from high and low upwelling environments. Mol Ecol. 2019;28:2715-30.

31. Carreiro-Silva M, Cerqueira T, Godinho A, Caetano M, Santos RS, Bettencourt R. Molecular mechanisms underlying the physiological responses of the cold-water coral Desmophyllum dianthus to ocean acidification. Coral Reefs. 2014:33:465-76.

32. Vidal-Dupiol J, Zoccola D, Tambutté E, Grunau C, Cosseau C, Smith KM, et al Genes related to ion-transport and energy production are upregulated in response to $\mathrm{CO}_{2}$-driven $\mathrm{pH}$ decrease in corals: new insights from transcriptome analysis. PLoS One. 2013;8:e58652.

33. Rivest EB, Kelly MW, DeBiasse MB, Hofmann GE. Host and symbionts in Pocillopora damicornis larvae display different transcriptomic responses to ocean acidification and warming. Front Mar Sci. 2018;5:186.

34. Davies SW, Marchetti A, Ries JB, Castillo KD. Thermal and $p \mathrm{CO}_{2}$ stress elicit divergent transcriptomic responses in a resilient coral. Front Mar Sci. 2016;3: $1-15$.

35. Zoccola D, Innocenti A, Bertucci A, Tambutté E, Supuran CT, Tambutté S. Coral carbonic anhydrases: regulation by ocean acidification. Mar Drugs. 2016;14:109.

36. Drake JL, Schaller MF, Mass T, Godfrey L, Fu A, Sherrell RM, et al. Molecular and geochemical perspectives on the influence of $\mathrm{CO}_{2}$ on calcification in coral cell cultures. Limnol Oceanogr. 2017;63:107-21.

37. Wäge J, Rotchell JM, Gambi MC, Hardege JD. Target gene expression studies on Platynereis dumerilii and Platynereis cfr massiliensis at the shallow $\mathrm{CO}_{2}$ vents off Ischia, Italy. Estuar Coast Shelf Sci. 2017;207:351-8.

38. Wäge J, Lerebours A, Hardege JD, Rotchell JM. Exposure to low pH induces molecular level changes in the marine worm, Platynereis dumerilii. Ecotoxicol Environ Saf. 2016;124:105-10.

39. Zippay ML, Hofmann GE. Effect of pH on gene expression and thermal tolerance of early life history stages of red abalone (Haliotis rufescens). J Shellfish Res. 2010;29:429-39.

40. Almeida Â, Freitas R, Calisto V, Esteves VI, Schneider RJ, Soares AMVM, et al. Effects of carbamazepine and cetirizine under an ocean acidification 
scenario on the biochemical and transcriptome responses of the clam Ruditapes philippinarum. Environ Pollut. 2018;235:857-68.

41. Peng C, Zhao X, Liu S, Shi W, Han Y, Guo C, et al. Ocean acidification alters the burrowing behaviour, Ca2+/Mg2+-ATPase activity, metabolism, and gene expression of a bivalve species, Sinonovacula constricta. Mar Ecol Prog Ser. 2017:575:107-17.

42. Kelly MW, Padilla-Gamiño JL, Hofmann GE. High $p \mathrm{CO}_{2}$ affects body size, but not gene expression in larvae of the California mussel (Mytilus californianus). ICES J Mar Sci. 2016;73:962-9.

43. Zhao X, Guo C, Han Y, Che Z, Wang Y, Wang X, et al. Ocean acidification decreases mussel byssal attachment strength and induces molecular byssal responses. Mar Ecol Prog Ser. 2017;565:67-77.

44. Pratt N, Ciotti BJ, Morgan EA, Stahl H, Stahl H, Hauton C. No evidence for impacts to the molecular ecophysiology of ion or $\mathrm{CO}_{2}$ regulation in tissues of selected surface-dwelling bivalves in the vicinity of a sub-seabed $\mathrm{CO}_{2}$ release. Int J Greenh Gas Control. 2015;38:193-201.

45. Hüning AK, Melzner F, Thomsen J, Gutowska MA, Krämer L, Frickenhaus S, et al. Impacts of seawater acidification on mantle gene expression patterns of the Baltic Sea blue mussel: implications for shell formation and energy metabolism. Mar Biol. 2013;160:1845-61.

46. De Wit P, Durland E, Ventura A, Langdon CJ. Gene expression correlated with delay in shell formation in larval Pacific oysters (Crassostrea gigas) exposed to experimental ocean acidification provides insights into shell formation mechanisms. BMC Genomics. 2018;19:1-15.

47. Cao R, Liu Y, Wang Q, Zhang Q, Yang D, Liu H, et al. The impact of ocean acidification and cadmium on the immune responses of Pacific oyster, Crassostrea gigas. Fish Shellfish Immunol. 2018;81:456-62.

48. Clark MS, Thorne MAS, Amaral A, Vieira F, Batista FM, Reis J, et al. Identification of molecular and physiological responses to chronic environmental challenge in an invasive species: the Pacific oyster, Crassostrea gigas. Ecol Evol. 2013;3:3283-97.

49. Chapman RW, Mancia A, Beal M, Veloso A, Rathburn C, Blair A, et al. The transcriptomic responses of the eastern oyster, Crassostrea virginica, to environmental conditions. Mol Ecol. 2011;20:1431-49.

50. Li S, Huang J, Liu C, Liu Y, Zheng G, Xie L, et al. Interactive effects of seawater acidification and elevated temperature on the transcriptome and biomineralization in the pearl oyster Pinctada fucata. Environ Sci Technol. 2016;50:1157-65.

51. Li S, Huang J, Liu C, Liu Y, Zheng G, Xie L, et al. Transcriptome and biomineralization responses of the pearl oyster Pinctada fucat a to elevated $\mathrm{CO}_{2}$ and temperature. Sci Rep. 2016;6:18943.

52. Liu W, Huang $X$, Lin J, He M. Seawater acidification and elevated temperature affect gene expression patterns of the pearl oyster Pinctada fucata. PLoS One. 2012;7:e33679.

53. Li S, Liu C, Zhan A, Xie L, Zhang R. Influencing mechanism of ocean acidification on byssus performance in the pearl oyster Pinctada fucata. Environ Sci Technol. 2017;51:7696-706.

54. Liu W, Yu Z, Huang $X$, Shi $Y$, Lin J, Zhang $H$, et al. Effect of ocean acidification on growth, calcification, and gene expression in the pearl oyster, Pinctada fucata. Mar Environ Res. 2017;130:174-80.

55. Goncalves P, Anderson K, Thompson EL, Melwani A, Parker LM, Ross PM, et al. Rapid transcriptional acclimation following transgenerational exposure of oysters to ocean acidification. Mol Ecol. 2016;25:4836-49.

56. Goncalves P, Jones DB, Thompson EL, Parker LM, Ross PM, Raftos DA. Transcriptomic profiling of adaptive responses to ocean acidification. Mol Ecol. 2017;26:5974-88.

57. Goncalves P, Thompson EL, Raftos DA. Contrasting impacts of ocean acidification and warming on the molecular responses of $\mathrm{CO}_{2}$-resilient oysters. BMC Genomics. 2017;18:1-15.

58. Maas AE, Lawson GL, Tarrant AM. Transcriptome-wide analysis of the response of the thecosome pteropod Clio pyramidata to short-term $\mathrm{CO}_{2}$ exposure. Comp Biochem Physiol - Part D Genomics Proteomics. 2015;16:1-9.

59. Thabet AA, Maas AE, Saber SA, Tarrant AM. Assembly of a reference transcriptome for the gymnosome pteropod Clione limacina and profiling responses to short-term $\mathrm{CO}_{2}$ exposure. Mar Genomics. 2017;34:39-45.

60. Moya A, Howes EL, Lacoue-Labarthe T, Forêt S, Hanna B, Medina M, et al. Nearfuture $\mathrm{pH}$ conditions severely impact calcification, metabolism and the nervous system in the pteropod Heliconoides inflatus. Glob Chang Biol. 2016;22:3888-900.

61. Koh HY, Lee JH, Han SJ, Park H, Shin SC, Lee SG. A transcriptomic analysis of the response of the arctic pteropod Limacina helicina to carbon dioxidedriven seawater acidification. Polar Biol. 2015;38:1727-40.
62. Johnson KM, Hofmann GE. Transcriptomic response of the Antarctic pteropod Limacina helicina antarctica to ocean acidification. BMC Genomics. 2017;18:812.

63. Maas AE, Lawson GL, Bergan AJ, Tarrant AM. Exposure to $\mathrm{CO}_{2}$ influences metabolism, calcification, and gene expression of the thecosome pteropod Limacina retroversa. J Exp Biol. 2018;221:jeb.164400.

64. Kriefall NG, Pechenik JA, Pires A, Davies SW. Resilience of Atlantic slippersnai Crepidula fornicata larvae in the face of severe coastal acidification. Front Mar Sci. 2018:5:346825.

65. Aguilera VM, Vargas CA, Lardies MA, Poupin MJ. Adaptive variability to low$\mathrm{pH}$ river discharges in Acartia tonsa and stress responses to high $\mathrm{pCO}_{2}$ conditions. Mar Ecol. 2016;37:215-26.

66. Bailey A, De Wit P, Thor P, Browman HI, Bjelland R, Shema S, et al. Regulation of gene expression is associated with tolerance of the Arctic copepod Calanus glacialis to $\mathrm{CO}_{2}$-acidified sea water. Ecol Evol. 2017;7: 7145-60.

67. De Wit P, Dupont S, Thor P. Selection on oxidative phosphorylation and ribosomal structure as a multigenerational response to ocean acidification in the common copepod Pseudocalanus acuspes. Evol Appl. 2016;9:1112-23.

68. Fehsenfeld $S$, Weihrauch D. Differential acid-base regulation in various gills of the green crab Carcinus maenas: effects of elevated environmental $p \mathrm{CO}_{2}$. Comp Biochem Physiol - A Mol Integr Physiol. 2013;164:54-65.

69. Fehsenfeld S, Kiko R, Appelhans Y, Towle DW, Zimmer M, Melzner F. Effects of elevated seawater $\mathrm{PCO}_{2}$ on gene expression patterns in the gills of the green crab, Carcinus maenas. BMC Genomics. 2011;12:488.

70. Schiffer M, Harms L, Lucassen M, Mark CC, Pörtner HO, Storch D. Temperature tolerance of different larval stages of the spider crab Hyas araneus exposed to elevated seawater $p \mathrm{CO}_{2}$. Front Zool. 2014;11:1-22.

71. Harms L, Frickenhaus S, Schiffer M, Mark FC, Storch D, Held C, et al. Gene expression profiling in gills of the great spider crab Hyas araneus in response to ocean acidification and warming. BMC Genomics. 2014;15:1-17.

72. Hu MY, Casties I, Stumpp M, Ortega-Martinez O, Dupont S. Energy metabolism and regeneration are impaired by seawater acidification in the infaunal brittlestar Amphiura filiformis. J Exp Biol. 2014;217:2411-21.

73. Kurihara H, Takano Y, Kurokawa D, Akasaka K. Ocean acidification reduces biomineralization-related gene expression in the sea urchin, Hemicentrotus pulcherrimus. Mar Biol. 2012;159:2819-26.

74. O'Donnell MJ, Todgham AE, Sewell MA, Hammond LM, Ruggiero K, Fangue NA, et al. Ocean acidification alters skeletogenesis and gene expression in larval sea urchins. Mar Ecol Prog Ser. 2010;398:157-71.

75. O'Donnell MJ, Hammond LM, Hofmann GE. Predicted impact of ocean acidification on a marine invertebrate: elevated $\mathrm{CO}_{2}$ alters response to thermal stress in sea urchin larvae. Mar Biol. 2009;156:439-46.

76. Martin S, Richier S, Pedrotti M-L, Dupont S, Castejon C, Gerakis Y, et al. Early development and molecular plasticity in the Mediterranean Sea urchin Paracentrotus lividus exposed to $\mathrm{CO}_{2}$-driven acidification. J Exp Biol. 2011; 214:1357-68.

77. Runcie DE, Dorey N, Garfield DA, Stumpp M, Dupont S, Wray GA. Genomic characterization of the evolutionary potential of the sea urchin Strongylocentrotus droebachiensis facing ocean acidification. Genome Biol Evol. 2016;8:3672-84.

78. Evans TG, Pespeni MH, Hofmann GE, Palumbi SR, Sanford E. Transcriptomic responses to seawater acidification among sea urchin populations inhabiting a natural pH mosaic. Mol Ecol. 2017;26:2257-75.

79. Evans TG, Chan F, Menge BA, Hofmann GE. Transcriptomic responses to ocean acidification in larval sea urchins from a naturally variable $\mathrm{pH}$ environment. Mol Ecol. 2013;22:1609-25.

80. Wong JM, Johnson KM, Kelly MW, Hofmann GE. Transcriptomics reveal transgenerational effects in purple sea urchin embryos: adult acclimation to upwelling conditions alters the response of their progeny to differential pCO $\mathrm{CO}_{2}$ levels. Mol Ecol. 2018;27:1120-37.

81. Todgham AE, Hofmann GE. Transcriptomic response of sea urchin larvae Strongylocentrotus purpuratus to $\mathrm{CO}_{2}$-driven seawater acidification. J Exp Biol. 2009;212:2579-94.

82. Padilla-Gamino JL, Kelly MW, Evans TG, Hofmann GE, et al. Temperature and $\mathrm{CO}_{2}$ additively regulate physiology, morphology and genomic responses of larval sea urchins, Strongylocentrotus purpuratus. Proc R Soc B. 2013;280: 20130155.

83. Pan T-CF, Applebaum SL, Manahan DT. Experimental Ocean acidification alters the allocation of metabolic energy. Proc Natl Acad Sci. 2015;112: 4696-701. 
84. Stumpp M, Wren J, Melzner F, Thorndyke MC, Dupont ST. $\mathrm{CO}_{2}$ induced seawater acidification impacts sea urchin larval development I: elevated metabolic rates decrease scope for growth and induce developmenta delay. Comp Biochem Physiol A Mol Integr Physiol. 2011;160:331-40.

85. Lee HG, Stumpp M, Yan JJ, Tseng YC, Heinzel S, Hu MYA, et al. Tipping points of gastric $\mathrm{pH}$ regulation and energetics in the sea urchin larva exposed to $\mathrm{CO}_{2}$-induced seawater acidification. Comp Biochem Physiol -Part A Mol Integr Physiol. 2019;234:87-97

86. Hammond LM, Hofmann GE. Early developmental gene regulation in Strongylocentrotus purpuratus embryos in response to elevated $\mathrm{CO}_{2}$ seawater conditions. J Exp Biol. 2012;215:2445-54.

87. Pespeni MH, Barney BT, Palumbi SR. Differences in the regulation of growth and biomineralization genes revealed through long-term common-garden acclimation and experimental genomics in the purple sea urchin. Evolution. 2013:67:1901-14.

88. Schunter C, Welch MJ, Ryu T, Zhang H, Berumen ML, Nilsson GE, et al. Molecular signatures of transgenerational response to ocean acidification in a species of reef fish. Nat Clim Chang. 2016;6:1014-8.

89. Schunter C, Welch MJ, Nilsson GE, Rummer JL, Munday PL, Ravasi T. An interplay between plasticity and parental phenotype determines impacts of ocean acidificaiton on a reef fish. Nat Ecol Evol. 2017;2(2):334

90. Crespel A, Zambonino-Infante JL, Mazurais D, Koumoundouros G, Fragkoulis S, Quazuguel P, et al. The development of contemporary European sea bass larvae (Dicentrarchus labrax) is not affected by projected ocean acidification scenarios. Mar Biol. 2017;164:1-12.

91. Michael K, Kreiss CM, Hu MY, Koschnick N, Bickmeyer U, Dupont S, et al. Adjustments of molecular key components of branchial ion and $\mathrm{pH}$ regulation in Atlantic cod (Gadus morhua) in response to ocean acidification and warming. Comp Biochem Physiol Part - B Biochem Mol Biol. 2016;193:33-46.

92. Hu MY, Michael K, Kreiss CM, Stumpp M, Dupont S, Tseng YC, et al. Temperature modulates the effects of ocean acidification on intestinal ion transport in Atlantic cod, Gadus morhua. Front Physiol. 2016;7:1-18.

93. Tseng YC, Hu MY, Stumpp M, Lin LY, Melzner F, Hwang PP. $\mathrm{CO}_{2}$-driven seawater acidification differentially affects development and molecular plasticity along life history of fish (Oryzias latipes). Comp Biochem Physiol A Mol Integr Physiol. 2013;165:1190-30.

94. Huth TJ, Place SP. RNA-seq reveals a diminished acclimation response to the combined effects of ocean acidification and elevated seawater temperature in Pagothenia borchgrevinki. Mar Genomics. 2016;28:87-97.

95. Allmon EB, Esbaugh AJ. Carbon dioxide induced plasticity of branchial acidbase pathways in an estuarine teleost. Sci Rep. 2017;7:45680.

96. Hamilton SL, Logan CA, Fennie HW, Sogard SM, Barry JP, Makukhov AD, et al. Species-specific responses of juvenile rockfish to elevated $p \mathrm{CO}_{2}$ : from behavior to genomics. PLoS One. 2013;49:45-53.

97. Huth TJ, Place SP. Transcriptome wide analyses reveal a sustained cellular stress response in the gill tissue of Trematomus bernacchii after acclimation to multiple stressors. BMC Genomics. 2016:17:1-18.

98. Lannig G, Eilers S, Pörtner HO, Sokolova IM, Bock C. Impact of ocean acidification on energy metabolism of oyster, Crassostrea gigas - changes in metabolic pathways and thermal response. Mar Drugs. 2010;8:2318-39.

99. Rivest EB, Hofmann GE. Responses of the metabolism of the larvae of Pocillopora damicornis to ocean acidification and warming. PLoS One. 2014; 9:e96172.

100. Putnam HM, Gates RD. Preconditioning in the reef-building coral Pocillopora damicornis and the potential for trans-generational acclimatization in coral larvae under future climate change conditions. J Exp Biol. 2015;218:2365-72.

101. Hoshijima U, Wong JM, Hofmann GE. Additive effects of $\mathrm{pCO}_{2}$ and temperature on respiration rates of the Antarctic pteropod Limacina helicina antarctica. Conserv Physiol. 2017:5:1-14.

102. Thomsen J, Melzner F. Moderate seawater acidification does not elicit longterm metabolic depression in the blue mussel Mytilus edulis. Mar Biol. 2010; 157:2667-76.

103. Gazeau F, Gattuso JP, Dawber C, Pronker AE, Peene F, Peene J, et al. Effect of ocean acidification on the early life stages of the blue mussel Mytilus edulis. Biogeosciences. 2010;7:2051-60.

104. Liu W, He M. Effects of ocean acidification on the metabolic rates of three species of bivalue from southern coast of China. Chin J Oceanol Limnol. 2012;30:206-11.

105. Parker LM, Ross PM, O'Connor WA, Borysko L, Raftos DA, Pörtner HO. Adult exposure influences offspring response to ocean acidification in oysters. Glob Chang Biol. 2012;18:82-92.
106. Calosi P, Rastrick SPS, Lombardi C, De Guzman HJ, Hardege D, Davidson L, et al. Adaptation and acclimatization to ocean acidification in marine ectotherms: an in situ transplant experiment with polychaetes at a shallow $\mathrm{CO}_{2}$ vent system. Proc R Soc B. 2013;368:20120444.

107. Bailey A, Thor P, Browman HI, Fields DM, Runge J, Vermont A, et al. Early life stages of the Arctic copepod Calanus glacialis are unaffected by increased seawater $p \mathrm{CO}_{2}$. ICES J Mar Sci. 2017;74:996-1004.

108. Thor $\mathrm{P}$, Dupont $\mathrm{S}$. Transgenerational effects alleviate severe fecundity loss during ocean acidification in a ubiquitous planktonic copepod. Glob Chang Biol. 2015;21:2261-71.

109. Dupont S, Dorey N, Stumpp M, Melzner F, Thorndyke M. Long-term and trans-life-cycle effects of exposure to ocean acidification in the green sea urchin Strongylocentrotus droebachiensis. Mar Biol. 2013;160:1835-43.

110. Stumpp M, Dupont S, Thorndyke MC, Melzner F. $\mathrm{CO}_{2}$ induced seawater acidification impacts sea urchin larval development II: gene expression patterns in pluteus larvae. Comp Biochem PhysiolA Mol Integr Physiol. 2011;160:320-30.

111. Strahl J, Francis D, Doyle J, Humphrey C, Fabricius K. Biochemical responses to ocean acidification contrast between tropical corals with high and low abundances at volcanic carbon dioxide seeps. ICES J Mar Sci. 2016;73:897-909.

112. Schoepf V, Grottoli AG, Warner ME, Cai WJ, Melman TF. Coral energy reserves and calcification in a high- $\mathrm{CO}_{2}$ world at two temperatures. PLoS One. 2013;8:e75049

113. Byrne M, Lamare M, Winter D, Dworjanyn SA, Uthicke S. The stunting effect of a high $\mathrm{CO}_{2}$ ocean on calcification and development in sea urchin larvae, a synthesis from the tropics to the poles. Philos Trans R Soc B Biol Sci. 2013; 368:20120439.

114. Wong JM, Kozal LC, Leach TS, Hoshijima U, Hofmann GE. Transgenerational effects in an ecological context: conditioning of adult sea urchins to upwelling conditions alters maternal provisioning and progeny phenotype. J Exp Mar Biol. 2019;1:1-13.

115. Gazeau F, Parker LM, Comeau S, Gattuso JP, O'Connor WA, Martin S, et al. Impacts of ocean acidification on marine shelled molluscs. Mar Biol. 2013. 160:2207-45.

116. Fitzer SC, Phoenix VR, Cusack M, Kamenos NA. Ocean acidification impacts mussel control on biomineralisation. Sci Rep. 2014;4:6218.

117. Zhao L, Yang F, Milano S, Han T, Walliser EO, Schöne BR. Transgenerational acclimation to seawater acidification in the Manila clam Ruditapes philippinarum: preferential uptake of metabolic carbon. Sci Total Environ. 2018;627:95-103.

118. Castillo KD, Ries JB, Bruno JF, Westfield IT. The reef-building coral Siderastrea siderea exhibits parabolic responses to ocean acidification and warming. Proc R Soc B Biol Sci. 2014;281:20141856.

119. Wong JM, Johnson KM, Kelly MW, Hofmann GE. Transcriptomics reveal transgenerational effects in purple sea urchins exposed to upwelling conditions, and the response of their progeny to differential $p \mathrm{CO}_{2}$ levels. Mol Ecol. 2018;27:1120.

120. Kong $H$, Jiang $X$, Clements JC, Wang $T$, Huang $X$, Shang $Y$, et al. Transgenerational effects of short-term exposure to acidification and hypoxia on early developmental traits of the mussel Mytilus edulis. Mar Environ Res. 2019;145:73

121. Moberg F, Folke C. Ecological goods and services of coral reef ecosystems. Ecol Econ. 1999;29:215-33.

122. Chan NCS, Connolly SR. Sensitivity of coral calcification to ocean acidification: a meta-analysis. Glob Chang Biol. 2013;19:282-90.

123. Cohen S, Krueger T, Fine M. Measuring coral calcification under ocean acidification: methodological considerations for the 45Ca-uptake and total alkalinity anomaly technique. PeerJ. 2017;5:1-21.

124. Mollica NR, Guo W, Cohen AL, Huang K, Foster GL, Donald HK. Ocean acidification affects coral growth by reducing skeletal density. Proc Natl Acad Sci. 2018:115:1754-9.

125. Fine $M$, Tchernov D. Scleractinian coral species survive and recover from decalcification. Science. 2007;315:1811.

126. Kültz D. Molecular and evolutionary basis of the cellular stress response. Annu Rev Physiol. 2005;67:225-57.

127. Feder ME, Hofmann GE. Heat-shock proteins, molecular chaperones, and the stress response: evolutionary and ecological physiology. Annu Rev Physiol. 1999;61:243-82.

128. Dove MC, Nell JA, O'Connor WA. Evaluation of the progeny of the fourthgeneration Sydney rock oyster Saccostrea glomerata (Gould, 1850) breeding lines for resistance to QX disease (Marteilia sydneyi) and winter mortality (Bonamia roughleyi). Aquac Res. 2013;44:1791-800. 
129. Parker LM, Ross PM, O'Connor WA. Populations of the Sydney rock oyster, Saccostrea glomerata, vary in response to ocean acidification. Mar Biol. 2011; 158:689-97.

130. Dineshram R, Chandramouli K, Ko GWK, Zhang H, Qian PY, Ravasi T, et al. Quantitative analysis of oyster larval proteome provides new insights into the effects of multiple climate change stressors. Glob Chang Biol. 2016;22:2054-68.

131. Heuer RM, Grosell M. Physiological impacts of elevated carbon dioxide and ocean acidification on fish. Am J Phys Regul Integr Comp Phys. 2014;307: R1061-84.

132. Heuer RM, Welch MJ, Rummer JL, Munday PL, Grosell M. Altered brain ion gradients following compensation for elevated $\mathrm{CO}_{2}$ are linked to behavioural alterations in a coral reef fish. Sci Rep. 2016;6:1-10.

133. Kreiss CM, Michael K, Lucassen M, Jutfelt F, Motyka R, Dupont S, et al. Ocean warming and acidification modulate energy budget and gill ion regulatory mechanisms in Atlantic cod (Gadus morhua). J Comp Physiol B Biochem Syst Environ Physiol. 2015;185:767-81.

134. Stumpp M, Hu MY, Melzner F, Gutowska MA, Dorey N, Himmerkus N, et al. Acidified seawater impacts sea urchin larvae $\mathrm{pH}$ regulatory systems relevant for calcification. Proc Natl Acad Sci U S A. 2012;109:18192-7.

135. Wong JM, Gaitán-espitia JD, Hofmann GE. Transcriptional profiles of early stage red sea urchins (Mesocentrotus franciscanus) reveal differential regulation of gene expression across development. Mar Genomics. 2019;48: 100692.

136. Tu Q, Cameron RA, Davidson EH. Quantitative developmental transcriptomes of the sea urchin Strongylocentrotus purpuratus. Dev Biol. 2014;385:160-7.

137. Nagelkerken I, Munday PL. Animal behaviour shapes the ecological effects of ocean acidification and warming: moving from individual to communitylevel responses. Glob Chang Biol. 2016;22:974-89.

138. Rosa R, Rummer JL, Munday PL. Biological responses of sharks to ocean acidification. Biol Lett. 2017;13:20160796

139. Tresguerres M, Hamilton TJ. Acid-base physiology, neurobiology and behaviour in relation to $\mathrm{CO}_{2}$-induced ocean acidification. J Exp Biol. 2017; 220:2136-48.

140. Briffa M, De K, Munday PL. High $\mathrm{CO}_{2}$ and marine animal behaviour: potential mechanisms and ecological consequences. Mar Pollut Bull. 2012; 64:1519-28.

141. Cattano C, Claudet J, Domenici P, Milazzo M. Living in a high $\mathrm{CO}_{2}$ world: a global meta-analysis shows multiple trait-mediated fish responses to ocean acidification. Ecol Monogr. 2018;88:320-35.

142. Draper AM, Weissburg MJ. Impacts of global warming and elevated $\mathrm{CO}_{2}$ on sensory behavior in predator-prey interactions: a review and synthesis. Front Ecol Evol. 2019;7:72.

143. Clements JC, Hunt HL. Marine animal behaviour in a high $\mathrm{CO}_{2}$ ocean. Mar Ecol Prog Ser. 2015:536:259-79.

144. Porteus CS, Hubbard PC, Uren Webster TM, van Aerle R, Canário AVM, Santos EM, et al. Near-future $\mathrm{CO}_{2}$ levels impair the olfactory system of a marine fish. Nat Clim Chang. 2018;8:737-43.

145. Nilsson GE, Dixson DL, Domenici P, McCormick MI, Sørensen C, Watson SA et al. Near-future carbon dioxide levels alter fish behaviour by interfering with neurotransmitter function. Nat Clim Chang. 2012:2:201-4.

146. Byrne M. Impact of ocean warming and ocean acidification on marine invertebrate life history stages: vulnerabilities and potential for persistence in a changing ocean. Oceanogr Mar Biol Annu Rev. 2011;49:1-42.

147. Gosselin LA, Qian PY. Juvenile mortality in benthic marine invertebrates. Mar Ecol Prog Ser. 1997;146:265-82.

148. Kurihara $\mathrm{H}$. Effects of $\mathrm{CO}_{2}$ driven ocean acidification on the early developmental stages of invertebrates. Mar Ecol Prog Ser. 2008;373:275-84.

149. Byrne M. Global change ecotoxicology: identification of early life history bottlenecks in marine invertebrates, variable species responses and variable experimental approaches. Mar Environ Res. 2012;76:3-15.

150. Byrne M, Przeslawski R. Multistressor impacts of warming and acidification of the ocean on marine invertebrates' life histories. Integr Comp Biol. 2013 53:582-96.

151. Christiansen FB, Fenchel TM. Evolution of marine invertebrate reproduction patterns. Theor Popul Biol. 1979;16:267-82.

152. Pechenik JA. On the advantages and disadvantages of larval stages in benthic marine invertebrate life cycles. Mar Ecol Prog Ser. 1999;177:269-97.

153. Dupont S, Dorey N, Thorndyke M. What meta-analysis can tell us about vulnerability of marine biodiversity to ocean acidification? Estuar Coast Shelf Sci. 2010;89:182-5.
154. Pechenik JA, Wendt DE, Jarrett JN. Metamorphosis is not a new beginning lanval experience influences juvenile performance. Bioscience. 1998;48:901-10.

155. Beckerman A, Benton TG, Ranta E, Veijo K, Lundberg P. Population dynamic consequences of delayed life-history effects. Trends Ecol Evol. 2002;17:263-9.

156. Veldhoen N, Ikonomou MG, Helbing CC. Molecular profiling of marine fauna: integration of omics with environmental assessment of the world's oceans. Ecotoxicol Environ. 2012;76:23-38.

157. Timmins-Schiffman E, O'Donnell MJ, Friedman CS, Roberts SB. Elevated $\mathrm{pCO}_{2}$ causes developmental delay in early larval Pacific oysters, Crassostrea gigas. Mar Biol. 2013;160:1973-82.

158. Przeslawski R, Webb AR. Natural variation in larval size and developmental rate of the northern quahog Mercenaria mercenaria and associated effects on larval and juvenile fitness. J Shellfish Res. 2009;28:505-10.

159. Evans TG, Watson-Wynn P. Effects of seawater acidification on gene expression: resolving broader-scale trends in sea urchins. Biol Bull. 2014;226:237-54.

160. Ishimatsu A, Hayashi M, Lee KS, Kikkawa T, Kita J. Physiological effects on fishes in a high- $\mathrm{CO}_{2}$ world. J Geophys Res C Ocean. 2005;110:1-8.

161. Mass T, Putnam HM, Drake JL, Zelzion E, Gates RD, Bhattacharya D, et al. Temporal expression pattern of biomineralization proteins during early development in the stony coral Pocillopora damicornis. Proc R Soc B. 2016; 283:20160322.

162. Feely RA, Sabine CL, Hernandez-Ayon JM, Ianson D, Hales B. Evidence for upwelling of corrosive "acidified" water onto the continental shelf. Science. 2008;320:1490-2.

163. Reum JCP, Alin SR, Harvey CJ, Bednarsek N, Wiley E, Feely RA, et al. Interpretation and design of ocean acidification experiments in upwelling systems in the context of carbonate chemistry co-variation with temperature and oxygen. ICES J Mar Sci. 2016;73:582-95.

164. Frieder CA, Nam SH, Martz TR, Levin LA. High temporal and spatial variability of dissolved oxygen and $\mathrm{pH}$ in a nearshore California kelp forest. Biogeosciences. 2012;9:3917-30.

165. Baumann $\mathrm{H}$, Wallace $\mathrm{RB}$, Tagliaferri $\mathrm{T}$, Gobler CJ. Large natural $\mathrm{pH}, \mathrm{CO}_{2}$ and $\mathrm{O}_{2}$ fluctuations in a temperate tidal salt marsh on diel, seasonal, and interannual time scales. Estuar Coasts. 2015;38:220-31.

166. Bopp L, Resplandy L, Orr JC, Doney SC, Dunne JP, Gehlen M, et al. Multiple stressors of ocean ecosystems in the 21st century: projections with CMIP5 models. Biogeosciences. 2013;10:6225-45.

167. Duarte CM, Hendriks IE, Moore TS, Olsen YS, Steckbauer A, Ramajo L, et al. Is ocean acidification an open-ocean syndrome? Understanding anthropogenic impacts on seawater pH. Estuar Coasts. 2013;36:221-36.

168. Przeslawski R, Byrne M, Mellin C. A review and meta-analysis of the effects of multiple abiotic stressors on marine embryos and larvae. Glob Chang Biol. 2015:21:2122-40.

169. IPCC. Climate change 2013: the physical science basis. In: Stocker TF, Qin D, Plattner G-K, Tignor M, Allen SK, Boschung JA, editors. Contribution of working group I to the fifth assessment report of the intergovernmental panel on climate change; 2013.

170. Keeling RF, Körtzinger A, Gruber N. Ocean deoxygenation in a warming world. Annu Rev Mar Sci. 2010;2:199-229.

171. Shaffer G, Olsen SM, Pedersen JOP. Long-term ocean oxygen depletion in response to carbon dioxide emissions from fossil fuels. Nat Geosci. 2009;2:105-9.

172. Bockmon EE, Frieder CA, Navarro MO, White-Kershek LA, Dickson AG. Technical note: controlled experimental aquarium system for multi-stressor investigation of carbonate chemistry, oxygen saturation, and temperature. Biogeosciences. 2013;10:5967-75.

173. Diffenbaugh NS, Snyder MA, Sloan LC. Could $\mathrm{CO}_{2}$-induced land-cover feedbacks alter near-shore upwelling regimes? Proc Natl Acad Sci. 2004;101:27-32.

174. Folt CL, Chen CY, Moore MV, Burnaford J. Synergism and antagonism among multiple stressors. Limnol Oceanogr. 1999;44:864-77.

175. Griffith GP, Fulton EA, Richardson AJ. Effects of fishing and acidificationrelated benthic mortality on the southeast Australian marine ecosystem. Glob Chang Biol. 2011;17:3058-74.

176. Harney E, Artigaud S, Le Souchu P, Miner P, Corporeau C, Essid H, et al. Non-additive effects of ocean acidification in combination with warming on the larval proteome of the Pacific oyster, Crassostrea gigas. J Proteome. 2016;135:151-61.

177. McNeil BI, Matear RJ, Barnes DJ. Coral reef calcification and climate change: the effect of ocean warming. Geophys Res Lett. 2004;31:1-4.

178. Breitburg DL, Salisbury J, Bernhard JM, Cai WJ, Dupont S, Doney SC, et al. And on top of all that ... coping with ocean acidification in the midst of many stressors. Oceanography. 2015;28:48. 
179. Borges AV. Present day carbon dioxide fluxes in the coastal ocean and possible feedbacks under global change. In: Oceans and the atmospheric carbon content; 2011.

180. Koop K, Booth D, Broadbent A, Brodie J, Bucher D, Capone D, et al. ENCORE: the effect of nutrient enrichment on coral reefs. Synthesis of results and conclusions. Mar Pollut Bull. 2001;42:91-120.

181. Pespeni MH, Chan F, Menge BA, Palumbi SR. Integrative and comparative biology signs of adaptation to local $\mathrm{pH}$ conditions across an environmental mosaic in the California current ecosystem. Integr Comp Biol. 2013;53:857-70.

182. González-Delgado S, Hernández JC. The importance of natural acidified systems in the study of ocean acidification: what have we learned? Adv Mar Biol. 2018;80:57-99.

183. Foo SA, Byrne M, Ricevuto E, Gambi MC. The carbon dioxide vents of Ischia, Italy, a natural system to assess impacts of ocean acidification on marine ecosystems: an overview of research and comparisons with other vent systems. Oceanogr Mar Biol Annu Rev. 2018;56:74.

184. Fabricius KE, Langdon C, Uthicke S, Humphrey C, Noonan S, De'ath G, et al. Losers and winners in coral reefs acclimatized to elevated carbon dioxide concentrations. Nat Clim Chang. 2011;1:165.

185. Uthicke S, Ebert T, Liddy M, Johansson C, Fabricius KE, Lamare M. Echinometra Sea urchins acclimatized to elevated $p \mathrm{CO}_{2}$ at volcanic vents outperform those under present-day $p \mathrm{CO}_{2}$ conditions. Glob Chang Biol. 2016;22:2451-61.

186. Migliaccio O, Pinsino A, Maffioli E, Smith AM, Agnisola C, Matranga V, et al. Living in future ocean acidification, physiological adaptive responses of the immune system of sea urchins resident at a $\mathrm{CO}_{2}$ vent system. Sci Total Environ. 2019;672:938-50

187. Hofmann GE, Smith JE, Johnson KS, Send U, Levin LA, Micheli F, et al. Highfrequency dynamics of ocean $\mathrm{pH}$ : a multi-ecosystem comparison. PLoS One. 2011;6:e28983.

188. Williams TD, Mirbahai L, Chipman JK. The toxicological application of transcriptomics and epigenomics in zebrafish and other teleosts. Brief Funct Genomics. 2014:13:157-71.

189. Reid NM, Whitehead A. Functional genomics to assess biological responses to marine pollution at physiological and evolutionary timescales: toward a vision of predictive ecotoxicology. Brief Funct Genomics. 2016;15:358-64.

190. Hauri C, Gruber N, Plattner G-K, Alin S, Feely RA, Hales B, et al. Ocean acidification in the California current system. Oceanography. 2009;22:60-71.

191. Kapsenberg L, Kelley AL, Shaw EC, Martz TR, Hofmann GE. Near-shore Antarctic $\mathrm{pH}$ variability has implications for the design of ocean acidification experiments. Sci Rep. 2015;5(9638):1-10.

192. Cameron RA, Samanta M, Yuan A, He D, Davidson E. SpBase: the sea urchin genome database and web site. Nucleic Acids Res. 2009;37:750-4

193. Davidson EH. The regulatory genome: gene regulatory networks in development and evolution. Burlington, San Diego, London: Elsevier; 2010

194. Langfelder P, Horvath S. WGCNA: an R package for weighted correlation network analysis. BMC Bioinformatics. 2008;9:559.

195. Matz MV. Fantastic beasts and how to sequence them: ecological genomics for obscure model organisms. Trends Genet. 2017;34:P121-32.

196. Garber M, Grabherr MG, Guttman M, Trapnell C. Computational methods for transcriptome annotation and quantification using RNA-seq. Nat Methods. 2011:8:469-77.

197. Martin JA, Wang Z. Next-generation transcriptome assembly. Nat Rev Genet. 2011;12:671-82.

198. Spies D, Ciaudo C. Dynamics in transcriptomics: advancements in RNA-seq time course and downstream analysis. Comput Struct Biotechnol J. 2015;13: 469-77.

199. Oliver ECJ, Donat MG, Burrows MT, Moore PJ, Smale DA, Alexander LV, et al. Longer and more frequent marine heatwaves over the past century. Nat Commun. 2018;9:1-12

200. Smale DA, Wernberg T, Oliver ECJ, Thomsen M, Harvey BP, Straub SC, et at. Marine heatwaves threaten global biodiversity and the provision of ecosystem services. Nat Clim Chang. 2019;9:306-12.

\section{Publisher's Note}

Springer Nature remains neutral with regard to jurisdictional claims in published maps and institutional affiliations.

\section{Ready to submit your research? Choose BMC and benefit from:}

- fast, convenient online submission

- thorough peer review by experienced researchers in your field

- rapid publication on acceptance

- support for research data, including large and complex data types

- gold Open Access which fosters wider collaboration and increased citations

- maximum visibility for your research: over $100 \mathrm{M}$ website views per year

At $\mathrm{BMC}$, research is always in progress.

Learn more biomedcentral.com/submissions 